(C2019, Elsevier. Licensed under the Creative Commons Attribution-NonCommercialNoDerivatives 4.0 International http://creativecommons.org/about/downloads 


\title{
Short and medium term financial-real cycles: An empirical assessment
}

\author{
Engelbert Stockhammer*, Robert Calvert Jump**, Karsten Kohler***, Julian Cavallero***
}

--- Accepted for publication in Journal of International Money and Finance ---

\begin{abstract}
Theories such as Minsky's financial instability hypothesis or New Keynesian financial accelerator models assign a key role to financial factors in business cycle dynamics. We propose a simple VAR-based estimation framework to examine some of the financial-real interaction mechanisms that are at the core of these theories. We examine cycle frequencies in seven OECD countries over the period 1970 to 2015, and find that output contains short- and medium business cycle frequencies, while interest rates, business debt, and household debt exhibit short-, medium- and long cycles, respectively. We find robust evidence for financialreal interaction mechanisms (i) at high frequencies between interest rates and GDP in Australia and the USA and (ii) at medium frequencies between business debt and GDP in Canada and Great Britain. The effect of interest rates and debt seems to operate via investment rather than consumption. We find no evidence for an interaction mechanism between household debt and GDP. Our results provide support for Minskyan and financial accelerator models in which output interacts with interest rates or corporate debt.
\end{abstract}

Key words: Minsky, financial accelerator, financial cycle, business cycle.

JEL codes: E32, G01.

Acknowledgements: Earlier versions of this paper were presented at the 2018 Analytical Political Economy workshop at the University of Cambridge, and a workshop at Kingston University. The authors are grateful to Vince Daly, Giorgos Gouzoulis, Andreas Joseph, Yun Kim, Maria Nikolaidi, Christian Proano, Christian Schoder, Chris Stewart, Roberto Veneziani, Rafael Wildauer and two anonymous referees. The usual disclaimers apply.

\footnotetext{
* Department of European and International Studies, King's College London. Virginia Woolf Building, 22 Kingsway, London, WC2B 6LE. Email: engelbert.stockhammer@kcl.ac.uk.

** Department of Accounting, Economics and Finance, University of the West of England, Coldharbour Ln, Stoke Gifford, Bristol BS16 1QY.

*** Department of Economics, Kingston University London, KT1 2EE, Kingston upon Thames, UK.
} 


\section{Introduction}

Theories of financially driven business cycles have enjoyed a resurgence of interest since the Global Financial Crisis of 2007-8. The literature takes a variety of theoretical standpoints, including Minskyan theories of financial instability (Minsky, 2008, 2016; Nikolaidi and Stockhammer, 2017), and New Keynesian theories of the financial accelerator (Kiyotaki and Moore, 1997; DeGrauwe and Macchiarelli 2015). Despite some disagreement about the exact channels, these theories share a common core. They all postulate an interaction mechanism between the financial and the real side of the economy that drives macroeconomic fluctuations. Expansions in real activity gradually lead to a financially fragile environment, which in turn has a negative effect on the real economy. The interplay of these two channels over time generates what we call a financial-real cycle.

Recent empirical research has highlighted different frequencies of business cycles on the one hand, and financial cycles on the other (Drehmann et al., 2012; Borio, 2014; Aikman et al., 2015; Strohsal et al., 2015). While regular business cycles in real activity are considered to exist with periods of up to 8 years, financial cycles appear to have a lower frequency with cycle lengths between 8 and 30 years (Borio, 2014). ${ }^{1}$ Real activity, however, has also been found to have medium-frequency fluctuations of around 10-12 years (Comin and Gertler, 2006; Drehmann et al., 2012).

Thus there is an interesting literature comparing financial and real cycles, but the empirical literature that exists to date has largely remained at a descriptive level. In particular, although there are some theoretical investigations of the subject (e.g. Kiyotaki and Moore 1997; Bernanke et al. 1999; Ryoo 2010, 2013a, 2016), there appear to be no empirical investigations attempting to disentangle the interaction mechanisms driving financial-real cycles. A recent exception is the study by Ma and Zhang (2016), which jointly estimates an output gap equation and an equation with a composite financial cycle index, along with other variables. They find that shocks to the financial cycle index explain up to $44 \%$ of the variance in the output gap and interpret this as evidence for an important role of the financial cycle in business cycle dynamics. However, the key source of fluctuations in this approach are exogenous shocks to the financial

\footnotetext{
1 The period (or length) of a cycle is measured by the number of time periods between two adjacent peaks (or troughs). The frequency of a cycle is the inverse of its length.
} 
cycle index, rather than an endogenous interaction mechanism between the financial and real economy. The contribution of the present paper is to estimate this endogenous interaction mechanism within a simple analytical framework.

To estimate the interaction mechanism behind financial-real cycles, we use a VAR-based method, in which the necessary conditions for the existence of an interaction cycle can be evaluated empirically. At the same time, the cycle period implied by the VAR can easily be computed, allowing us to map specific interaction mechanisms onto specific cycle lengths. The model is estimated for seven OECD countries over the period 1970 to 2015 . We find robust evidence for a financial-real interaction mechanism, (i) at high frequencies between interest rates and GDP in Australia and the USA, (ii) at low frequencies between business debt and GDP in Canada and Great Britain. Further estimations suggest that the effects of financial variables operate mainly through investment rather than consumption. We find no robust evidence for a financial-real interaction mechanism in Germany, Finland, or France, and no evidence for an interaction mechanism between household debt and GDP.

The focus of this paper on interest rates and debt rather than asset prices requires some clarification. In the theoretical Minskyan literature, there are broadly two types of models: those that focus on debt and interest rate dynamics, and those in which expectations about asset prices drive the cycle (Nikolaidi and Stockhammer, 2017). In the models in Ryoo (2010, 2013a, 2016), as well as benchmark financial accelerator models (Kiyotaki and Moore, 1997; Bernanke et al., 1999), debt and asset prices jointly play a role, as procyclical asset prices relax collateral constraints and allow for more borrowing during the boom. In this paper, we leave the integration of asset prices to future work. As this is the first attempt to disentangle financialreal interaction mechanisms empirically, it makes sense to start with simple bivariate mechanisms, which are analytically tractable and provide a clear intuition for the interaction mechanism. Asset prices are commonly endogenous in the theoretical literature, but not state variables (e.g. Kiyotaki and Moore, 1997; Ryoo 2010; we return to this point below). The reduced forms of Kiyotaki and Moore (1997) and Asada (2001), for instance, are thus bivariate models in business debt and output (or the capital stock). Our empirical approach can be viewed as a straightforward empirical test of this type of model.

The remainder of the paper is structured as follows. Section 2 provides a short review of the literature on financially driven business cycles and financial cycles. Section 3 presents a simple 
empirical framework for investigating financial-real cycles. Section 4 describes the data set and presents stylized facts. Section 5 presents the main estimation results with GDP as the real variable as well as robustness tests, while section 6 provides further estimations with those subcomponents of GDP which are expected to be affected by the financial variables. Section 7 concludes.

\section{Financial-real cycles: A brief review of the theory}

There are two contemporary research programmes examining financial-real cycles: the Minskyan and the New Keynesian literature. Hyman Minsky's financial instability hypothesis (Minsky, 2008; Minsky, 2016) has become a classic account of financially driven business cycles, which has slowly moved into the mainstream since the 2007-8 crises (Eggertsson and Krugman, 2012). A key aspect of Minsky's theory is the claim that financial fragility increases during economic expansions. Specifically, during periods of confidence, firms increase their investment and adopt increasingly risky financial positions to do so. At a certain point, due to accelerator effects, debt overhang, or endogenous increases in interest rates, a tipping point is followed by a downturn.

A sizeable theoretical literature studies various formalisations of Minsky's financial instability hypothesis, a large part of which is surveyed in Nikolaidi and Stockhammer (2017). Some authors assign a key role to the rate of interest in the cycle mechanism (Foley, 1987; Fazzari et al., 2008), and a small number to household debt (Ryoo, 2016; Palley, 1994), but the vast majority focus on corporate debt. While most papers appear to assume financial-real cycles at business cycle frequency, Ryoo (2010; 2013a; 2016) offers various models in which low frequency financial cycles in business or household debt and asset prices coexist with high frequency business cycles.

The benchmark New Keynesian model of financially driven business cycles is the financial accelerator model (Kiyotaki and Moore, 1997; Bernanke et al., 1999). In a similar manner to Minsky's theory, balance sheets play an important role, creating a link between the financial and the real economy. As asset prices inflate over the business cycle, credit constraints relax, and the credit supply exerts a pro-cyclical effect. This mechanism is integrated into the standard 
New Keynesian model, so that stochastic shocks create output fluctuations that are amplified by the financial accelerator.

In Kiyotaki and Moore (1997), credit limits vary endogenously over the business cycle due to their dependence on pro-cyclical asset prices. A predator-prey mechanism between debt and asset holdings then generates damped oscillations: a rise in asset prices increase net worth, which leads to more borrowing. Higher leverage, in turn, reduces aggregate demand which pulls down asset prices. Similarly, in Bernanke et al. (1999), a shock may lead to an increase in investment and asset prices. Recently, the financial accelerator has been integrated into behavioural models of business cycle dynamics in which heterogeneous agents and credit networks allow for a rich description of the propagation process of adverse shocks (Delli Gatti et al., 2010; Bofinger et al., 2013; De Grauwe and Macchiarelli, 2015).

Notably, while some of these theoretical studies consider the impact of asset prices, these typically do not enter the reduced-forms of these models as they are not state variables. For instance, in Kiyotaki and Moore (1997), asset prices are determined by a static function of the capital and corporate debt stocks, and therefore do not enter the reduced form model. In Ryoo (2013a) the cycle mechanism is based on the interaction of two different valuation strategies, often named fundamentalists and chartists, the effects of which may spill over to the real economy. The relevant state variables are the corporate debt to capital ratio, household portfolio composition, and the expected return on equity. The model is thus inherently more complex than the other financial-real interaction models discussed in this section.

Given the foregoing, the present study is an empirical examination of that part of the business cycle literature which focuses on the reduced-form interaction between interest rates and the real economy, and debt stocks and the real economy. This is consistent with the role of asset prices in New Keynesian financial accelerator models, but we do not study the more elaborate role of asset price expectations and portfolio choice discussed in parts of the Minskyan literature. In the next section we propose a simple empirical framework in which financial-real interaction mechanisms, defined in this way, can be examined.

\section{A simple empirical framework for financial-real cycles}




\subsection{The mathematical framework}

The cycle-generating interaction mechanism that is at the heart of financially driven business cycle theories can be formalised in a straightforward manner. Consider a simple bivariate system of difference equations in which a real variable $(y)$ and a financial variable $(f)$ interact with each other over time,

$$
\left[\begin{array}{l}
y_{t} \\
f_{t}
\end{array}\right]=\left[\begin{array}{ll}
\alpha_{1} & \alpha_{2} \\
\beta_{1} & \beta_{2}
\end{array}\right]\left[\begin{array}{l}
y_{t-1} \\
f_{t-1}
\end{array}\right]
$$

where we have suppressed constant terms for clarity. The system in (1) is consistent with the reduced forms of the financial accelerator model in Kiyotaki and Moore (1997, p. 235), and the Minsky model in Asada (2001, p. 79), for example. The Jacobian matrix $\boldsymbol{J}$ of (1) has the following structure,

$$
\boldsymbol{J}=\left[\begin{array}{ll}
J_{11} & J_{12} \\
J_{21} & J_{22}
\end{array}\right]=\left[\begin{array}{ll}
\alpha_{1} & \alpha_{2} \\
\beta_{1} & \beta_{2}
\end{array}\right]
$$

Oscillations in (1) exist when the eigenvalues of the Jacobian in (2) are complex conjugates. As the eigenvalues $\lambda$ are the roots of the characteristic equation,

$$
\lambda^{2}-\lambda \operatorname{Tr}(J)+\operatorname{Det}(J)=0,
$$

with roots,

$$
\lambda_{ \pm}=\frac{\operatorname{Tr}(J) \pm \sqrt{\operatorname{Tr}(J)^{2}-4 \operatorname{Det}(J)}}{2},
$$

the condition for oscillations can be expressed in terms of the discriminant $\Delta$ which must be negative for complex eigenvalues. This condition can be written as follows,

$$
\begin{aligned}
\Delta & =\operatorname{Tr}(J)^{2}-4 \operatorname{Det}(J)<0 \\
& =\left(J_{11}+J_{22}\right)^{2}-4\left(J_{11} J_{22}-J_{21} J_{12}\right)<0 \\
& =\left(J_{11}-J_{22}\right)^{2}+4 J_{21} J_{12}<0 .
\end{aligned}
$$


The first term of the condition is always positive. Then it is immediate that a necessary condition for the existence of oscillations must be $J_{21} J_{12}<0$, or $\alpha_{2} \beta_{1}<0$ in (1) and (2). This condition has a clear economic intuition: oscillatory dynamics in the system in (1) can only emerge if there is an interaction mechanism between the two state variables of the system by which an increase in one variable induces an acceleration of the second variable, which in turn drags down the first. As will be argued in more detail below, theories of financial-real cycles typically assume that increases in financial variables such as interest rates or debt exert a negative effect on GDP $\left(\alpha_{2}<0\right)$, whereas increases in GDP exert a positive effect on financial variables $\left(\beta_{1}>0\right)$.

\subsection{A simple illustration}

To provide an illustration of the outcome of such an interaction mechanism, we provide two numerical examples. Figure 1 displays simulations for a stochastic version of the system in (1) with uncorrelated white noise error terms added to each equation. In both parameterisations we set $\alpha_{2}<0$ and $\beta_{1}>0$, assuming a negative effect of the financial on the real variable and a positive effect of the real on the financial variable. The upper panel is based on the parameterisation $\alpha_{1}=0.4, \alpha_{2}=-0.8, \beta_{1}=0.4, \beta_{2}=0.9$. In the second parameterisation displayed in the lower panel, we leave the interaction between the two variables unchanged and only swap the elements of the main diagonal of the Jacobian matrix in (2), yielding $\alpha_{1}=$ $0.9, \alpha_{2}=-0.8, \beta_{1}=0.4, \beta_{2}=0.4$. 
Figure 1: Numerical simulation of the system in (1) for two different parameterisations
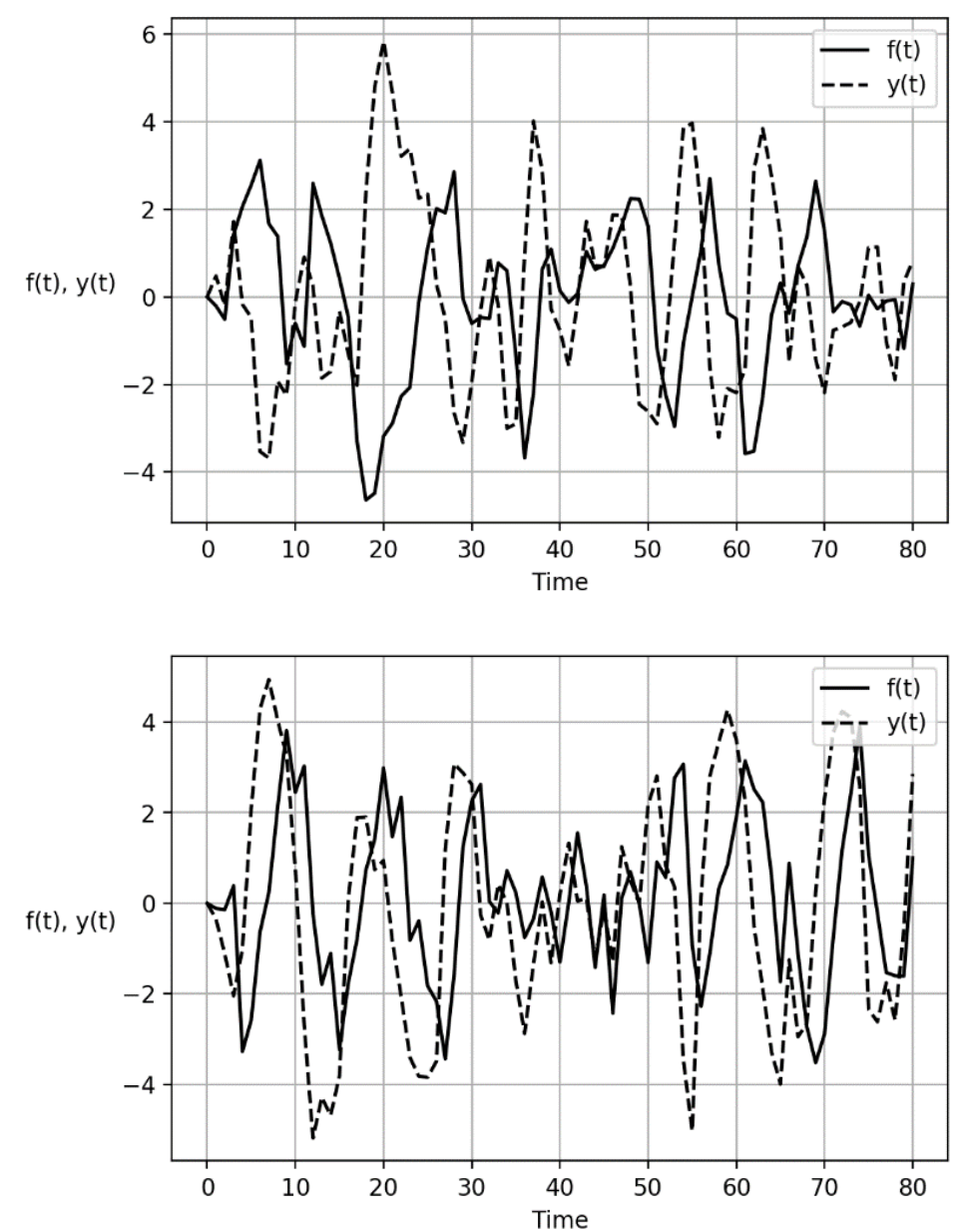

Notes: Uncorrelated white noise error terms were added to each equation in (1). The upper panel is based on the parameterisation $\alpha_{1}=0.4, \alpha_{2}=-0.8, \beta_{1}=0.4, \beta_{2}=0.9$ and the lower panel on $\alpha_{1}=0.9, \alpha_{2}=-0.8, \beta_{1}=$ $0.4, \beta_{2}=0.4$. The modulus for both parameterisations is 0.825 , so that the system is asymptotically stable. The correlation coefficients between the two series are -0.42 (upper panel) and 0.28 (lower panel).

Cyclical behaviour is apparent in both variables in the upper and lower panels of Figure 1. In the upper panel, peaks and troughs in $y$ and $f$ are out of phase, and the two variables undergo periods of joint expansion as well as periods where one variable expands while the other contracts. In contrast, the simulation in the second panel displays a much stronger phase synchronisation. As a result, there is a negative correlation of approximately -0.42 in the first simulation, and a positive correlation of approximately 0.28 in the second simulation. In the context of business cycle analysis, one would describe the financial variable in the first simulation as counter-cyclical, and in the second simulation as pro-cyclical. It is thus important to note that the existence of a financial-real interaction mechanism is consistent with a variety of contemporaneous correlations between the financial and real variables. This illustrates the 
importance of estimating interaction mechanisms directly, rather than relying solely on descriptive statistics.

\subsection{Specific interaction mechanisms: GDP, interest rates, and debt}

In the models estimated below, we use the log of real GDP $(G D P)$ for the real variable in (1). As different financial variables feature prominently in the theoretical literature discussed in section 2, we consider the short-term real interest rate (INTR), the ratio of non-financial corporation debt to GDP (NFCD), and the ratio of household debt to GDP (HHD). We use debt to income ratios rather than the level of debt because the negative effects of rising debt assumed in the theoretical literature typically hinge on the deteriorating financial robustness of economic units, which can be proxied by debt to income ratios. In robustness tests, we also use the capital stock as an alternative denominator.

To see how each of these financial variables interact with output, consider the interest rate first. If the central bank follows a Taylor rule with an output gap in its loss function, one would expect rising policy rates during boom periods and a lowering of interest rates during recessions. ${ }^{2}$ Rising interest rates during the boom can reduce aggregate output via a contractionary effect on either investment or consumption. The effect on investment may be due to a reduction of internal sources of finance, i.e. the net worth of the firm (Kalecki, 1937; Ndikumana, 1999; Bernanke et al., 1999). Contractionary effects on consumption are expected if households increase their savings to smooth consumption, or due to a redistribution of income to creditors with a lower propensity to consume.

Now consider business debt. While in supply-determined models where agents are creditconstrained, increases in debt and the flow of credit lead to increases in output (e.g. Biggs et al., 2009), in the Minskyan theoretical literature high levels of corporate debt will generally discourage business investment. This is because borrowers' and lenders' risk increase in debt and drive up the cost of long-term external finance (Minsky, 2008, pp. 104-110). In Bernanke et al. (1999), rising corporate leverage raises the external finance premium, thereby depressing capital formation. Indeed, a negative effect of leverage ratios on business investment has been

\footnotetext{
2 Note that while Minsky (2016) explicitly mentions monetary policy as the key channel behind the interest rate mechanism, Minsky models such as Foley (1987) and Fazzari et al. (2008) discuss rising risk premia or inflation that drives up (nominal) interest rates.
} 
confirmed in empirical studies (Fazzari et al., 1988; Ndikumana, 1999). From a long-run perspective, Arcand et al. (2015) discuss a hump-shaped relation between debt and output, where increases in debt have positive effects on output for low debt ratios because financial sector development can improve allocative efficiency.

Next consider household debt which also acts as a dampening factor in the financial accelerator models discussed in section 2. Negative effects household debt ratios on output have been found empirically (Mian et al., 2015; IMF, 2017, chap. 2). One would expect the contractionary effect of household debt to run mostly via consumption and/or residential investment, which are the components of aggregate output that are directly linked to the spending decisions of households. Notably, the effects of the level versus the change in debt may be opposite, as debt constitutes a (re-)payment obligation whereas new credit allows for more spending. Indeed, Palley (1994) and Kim $(2013,2016)$ find an expansionary effect of the change in household credit, but negative effects of debt in levels. It is thus important to note that the negative effects of debt on the dynamics of real activity refers to the stock of debt, rather than the flow.

Finally, an expansion of real output encourages a relaxation of lending standards and rising asset prices in the class of models considered in section 2, and therefore has an expansionary effect on leverage ratios. Indeed, Minsky (2008 [1975], p. 110) famously argued that, 'during a boom the ratio of debt-financing to investment increases', so that an increasing number of economic units rely on what he called 'Ponzi finance' (Minsky, 2016 [1982]). Similarly, in Kiyotaki and Moore (1997) and Bernanke et al. (1999), economic expansions go hand in hand with an improvement in the net worth of economic units, thereby relaxing credit constraints.

Notably, the assumption of increasing firm leverage ratios during the boom has been a contested issue in the Minskyan literature (Lavoie and Seccareccia, 2001; Lavoie, 2014, chap. 6; Charles, 2016). Lavoie and Seccareccia (2001) question the assumption that debt necessarily rises (decreases) during economic expansion (contractions). They point out that there can be a paradox of debt: while individual firms might increase investment in order to reach a target leverage ratio, this could fail if many firms do the same, as the resulting investment boom increases aggregate retained earnings which reduces the demand for external finance. However, Charles (2016) shows in a simple model that for a range of plausible parameter values, investment increases faster than retained earnings during economic expansions, particularly if the retention rate is relatively low. Furthermore, note that the Minskyan assumption of a 
positive effect of output on debt dynamics is consistent with both positive and negative contemporaneous correlations between debt ratios and output, as illustrated in section 3.2.

Based on the foregoing, it can be concluded that the theoretical literature on financial-real cycles typically predicts $\alpha_{2}<0$ and $\beta_{1}>0$ in (5), yielding the necessary condition $\alpha_{2} \beta_{1}<0$ for oscillations. Other configurations are possible: if firms are credit constrained, debt may have a positive effect on growth $\alpha_{2}>0$. If the paradox of debt holds, $\beta_{1}<0$. We now turn to the VAR models that operationalise the system in (1), allowing us to test the empirical relevance of the condition assumed in financial-real cycle models.

\subsection{The estimation framework}

As a system of difference equations is closely related to a VAR model, in principle the system in (1) can be estimated in a straightforward manner by the addition of a vector white noise error process. However, the system in (1) is almost certainly an over-simplification of the data generating process, which may be a higher-dimensional, higher-order dynamic system. In principle, almost any linear dynamic system can be approximated by a VAR with sufficient lags (Lütkepohl, 2005, chap. 15) and if these higher-order lags are omitted from the estimated model, they will be reflected in serial correlation in the error terms. To allow us to estimate the financial-real interaction mechanism without misrepresenting the data generating process, the fully specified empirical framework for financial-real cycles utilised in the present paper is as follows,

$$
\left[\begin{array}{l}
y_{t} \\
f_{t}
\end{array}\right]=\left[\begin{array}{l}
\alpha_{0} \\
\beta_{0}
\end{array}\right]+\left[\begin{array}{ll}
\alpha_{1} & \alpha_{2} \\
\beta_{1} & \beta_{2}
\end{array}\right]\left[\begin{array}{l}
y_{t-1} \\
f_{t-1}
\end{array}\right]+\left[\begin{array}{l}
u_{y t} \\
u_{f t}
\end{array}\right]
$$

with,

$$
\left[\begin{array}{l}
u_{y t} \\
u_{f t}
\end{array}\right]=\sum_{i=1}^{p} \boldsymbol{A}_{i}\left[\begin{array}{l}
u_{y t-i} \\
u_{f t-i}
\end{array}\right]+\left[\begin{array}{l}
\epsilon_{y t} \\
\epsilon_{f t}
\end{array}\right]
$$

where $\epsilon_{y t}$ and $\epsilon_{f t}$ are white noise error terms, and $\boldsymbol{A}_{i}$ are diagonal parameter matrices. Substituting (3) into (4) and re-arranging, we have, 


$$
\left[\begin{array}{l}
y_{t} \\
f_{t}
\end{array}\right]=\left[\begin{array}{l}
\alpha_{0} \\
\beta_{0}
\end{array}\right]+\left[\begin{array}{ll}
\alpha_{1} & \alpha_{2} \\
\beta_{1} & \beta_{2}
\end{array}\right]\left[\begin{array}{l}
y_{t-1} \\
f_{t-1}
\end{array}\right]+\sum_{i=1}^{p} \boldsymbol{A}_{i}\left(\left[\begin{array}{l}
y_{t-i} \\
f_{t-i}
\end{array}\right]-\left[\begin{array}{l}
\alpha_{0} \\
\beta_{0}
\end{array}\right]+\left[\begin{array}{ll}
\alpha_{1} & \alpha_{2} \\
\beta_{1} & \beta_{2}
\end{array}\right]\left[\begin{array}{l}
y_{t-i-1} \\
f_{t-i-1}
\end{array}\right]\right)+\left[\begin{array}{l}
\epsilon_{y t} \\
\epsilon_{f t}
\end{array}\right]
$$

which is a VAR with $p$ lags in which $\alpha_{2}$ and $\beta_{1}$ are the only parameters which are uniquely identified. ${ }^{3}$ By estimating the higher-order VAR in (5), we can therefore evaluate the necessary condition for the existence of financial-real cycles in (1), i.e. $\alpha_{2} \beta_{1}<0$ and assess whether the theoretical condition $\alpha_{2}<0, \beta_{1}>0$ is empirically valid.

The VAR approach also allows us to obtain the eigenvalues of the Jacobian matrix of the system. If there is at least one pair of complex conjugate eigenvalues, the implied cycle length can be calculated. To see this more clearly, consider the complex conjugate pair of eigenvalues $\lambda=h \pm \Omega i$. Its polar form is $\lambda=R(\cos \theta \pm i \cdot \sin \theta)$, where $R=\sqrt{h^{2}+\Omega^{2}}$ is the modulus and $\theta$ is an angle measured in radians. In the solution to the VAR model in (5), the eigenvalues will appear in the form $\lambda^{t}$. By De Moivre's theorem, this expression can be transformed into polar form as follows: $\lambda^{t}=[R(\cos \theta \pm i \cdot \sin \theta)]^{t}=R^{t}(\cos \theta t \pm i \cdot \sin \theta t)$. In the latter trigonometric expression, the implied length of the cycles is given by $\frac{2 \pi}{\theta}=\frac{2 \pi}{\arccos \left(\frac{h}{R}\right)}$. Thus, each pair of complex eigenvalues of the estimated system in (5) corresponds to a distinct cycle frequency in the solution path (Shibayama, 2008).

\section{Data and stylized facts}

The dataset is at annual frequency and consists of seven OECD countries: Australia, Canada, France, Finland, Germany, Great Britain, and the United States. Depending on the financial variable, the sample size ranges from 1970 to $2015 .{ }^{4}$ The data are at annual frequency for two reasons. First, the lag length multiplies rapidly when quarterly data is used, which in turn multiplies the potential pairs of complex eigenvalues. This would considerably reduce the interpretability of the estimates, making the identification of financial-real cycles effectively

\footnotetext{
${ }^{3}$ In practice, as most of the parameters in (5) are not uniquely identified, we estimate unrestricted VAR(p) models. To determine the lag length, we start with a minimum lag length of 2, unless the Bayesian Information Criterion (BIC) suggests a higher value. We then check for serial correlation in the residuals and successively increase the number of lags until all serial correlation is removed. Note that we impose a minimum lag length of 2 to permit complex eigenvalues (oscillatory dynamics) even when $\alpha_{2} \beta_{1} \nless 0$.

${ }^{4}$ A detailed description of our dataset can be found in Table Alin the online appendix.
} 
impossible. Second, the use of annual data allows us to avoid seasonal adjustment filters, which potentially induce spurious cyclical dynamics (Ghysels et al. 1993). While the use of annual data reduces the number of observations, we consider this cost to be outweighed by the foregoing benefits.

Augmented Dickey Fuller (ADF) unit root tests suggest the presence of a unit root for GDP, in all countries. ${ }^{5}$ For INTR, we also fail to reject the null hypothesis of a unit root in all countries. For both debt ratios we find unit roots for all countries, although in the case of $H H D$ we reject the null of a unit root in Great Britain and the United States when a trend term is included. For $N F C D$, inclusion of a linear trend renders $N F C D$ trend-stationary only in Australia. As unit root tests are known to have low power, we also use Pesaran (2007) cross-sectionally augmented ADF tests. The Pesaran (2004) cross sectional dependence (CD) tests (see Table A3 in online appendix) rejects the null hypothesis of no CD for GDP, INTR, NFCD, and $H H D$. The cross-sectionally augmented ADF tests suggest unit roots in GDP, NFCD and $H H D$, confirming the results from the simple ADF tests. However, the null hypothesis of a unit root in INTR is rejected (see Table A4 in the online appendix). Lastly, we investigate the possibility of cointegration between GDP and our three financial variables. We estimate Westerlund (2007) error correction-based panel cointegration tests (see Table A5 the in online appendix). The tests fail to reject the null hypothesis of no cointegration between GDP and NFCD and $H H D$, respectively. Overall, there is thus no evidence for cointegration between our key variables which simplifies the interpretation of the VARs.

Table 1 presents the results of spectral analysis on all series; this allows us to identify which frequencies make the largest contribution to the overall variance of the system (Hamilton, 1994, chap. 6). In order to obtain stationary series, we use two different methods: first differencing and bandpass (BP) filtering. ${ }^{6}$ Following the literature on financial cycles (Drehmann et al., 2012; Aikman et al., 2015), we extract fluctuations with a length between 8 and 30 years from the debt-to-GDP series. For interest rates, we use a more standard business cycle frequency

\footnotetext{
${ }^{5}$ See Table A2 in the online appendix. The optimal lag length for the ADF test equations was chosen based on the Bayesian Information Criterion (BIC). We performed tests with drift only, and with drift and time trend.

${ }^{6}$ We used the Christiano-Fitzgerald method with a symmetric and fixed lead/lag length of 3 years for all bandpassfiltered series in this article.
} 
with a length between 2 and 8 years. GDP was filtered at the 8-30 year frequency. ${ }^{7}$ For INTR, $N F C D$, and $H H D$, we report the local maximum of the spectral density function to obtain the cycle frequency that contributes most to the overall variance. For GDP, we report two local maxima.

\footnotetext{
${ }^{7}$ Estimating the spectral density functions for GDP on BP-filtered data at the range of 2-8 years yielded an average cycle length of $5 \frac{1}{2}$ years, which is almost identical to the average length of $51 / 3$ years obtained with differenced data. We thus focus on the longer range of 8-30 years.
} 
Table 1: Cycle length (in years) according to spectral density function

\begin{tabular}{|c|c|c|c|c|c|c|}
\hline Country & $\begin{array}{l}\text { Detrending } \\
\text { method }\end{array}$ & $G D P$, Max 1 & $G D P, \operatorname{Max} 2$ & INTR & NFCD & $H H D$ \\
\hline \multirow[t]{2}{*}{ AUS } & Diff & 4.40 & 8.80 & 4.40 & 7.60 & $\mathrm{n} / \mathrm{a}$ \\
\hline & $\mathrm{BP}$ & 7.80 & 4.33 & 3.90 & 6.60 & 16.50 \\
\hline \multirow{2}{*}{ CAN } & Diff & 15.00 & 5.62 & 2.75 & 9.00 & 15.00 \\
\hline & BP & 10 & 2.67 & 2.60 & 8.00 & 10.00 \\
\hline \multirow[t]{2}{*}{ DEU } & Diff & 5.62 & 3.46 & 3.38 & 9.00 & 22.50 \\
\hline & $\mathrm{BP}$ & 5.71 & 10 & 3.90 & 8.00 & 13.33 \\
\hline \multirow[t]{2}{*}{ FIN } & Diff & 15.00 & 7.50 & 2.37 & 7.50 & 15.00 \\
\hline & BP & 8 & 13.33 & 6.67 & 8.00 & 13.33 \\
\hline \multirow[t]{2}{*}{ FRA } & Diff & 15.00 & 5.62 & 3.38 & 9.50 & 19.00 \\
\hline & $\mathrm{BP}$ & 8 & 3.08 & 3.55 & 8.25 & 16.50 \\
\hline \multirow[t]{2}{*}{ GBR } & Diff & 5.00 & 9.00 & 3.08 & 19.50 & 15.00 \\
\hline & $\mathrm{BP}$ & 8 & 2.86 & 2.91 & 8.50 & 20.00 \\
\hline \multirow[t]{2}{*}{ USA } & Diff & 5.50 & 14.67 & 2.59 & 9.00 & 15.00 \\
\hline & BP & 5.57 & 9.75 & 2.60 & 10.00 & 13.33 \\
\hline \multirow[t]{3}{*}{ Average length } & Diff & & & 3.14 & 10.16 & 16.92 \\
\hline & $\mathrm{BP}$ & & & 3.73 & 8.19 & 14.42 \\
\hline & & Long $G D P$ cycle & Short $G D P$ cycle & & & \\
\hline \multirow{2}{*}{$\begin{array}{l}\text { Average } \\
\text { length }\end{array}$} & Diff & 11.87 & 5.30 & & & \\
\hline & $\mathrm{BP}$ & 8.96 & 5.20 & & & \\
\hline
\end{tabular}

Notes: AUS: Australia; CAN: Canada; DEU: Germany; FIN: Finland; FRA: France; GBR: Great Britain; USA: United States. BP: Bandpass-filtered with bounds from 8 to 30 years (GDP, NFCD, HHD) or 2 to 8 years (INTR) under the assumption of nonstationarity. Diff: First-differenced series. Cycle lengths were obtained from the local maximum of estimated spectral density functions using a Bartlett window and a truncation parameter of 20. For some shorter series, truncation parameters of 19 or 18 were used. To identify the second local maximum in GDP, we imposed the condition that it must differ from the first maximum by at least $3 \frac{1}{2} 2$ years. For Australia, no cycle frequency for $H H D$ could be obtained for the differenced series, as the maximum occurred at zero frequency. Average long $G D P$ cycle length is the average over the higher of the two local maxima in $G D P$, whereas the average short $G D P$ cycle length is the average over the lower of the two local maxima in GDP.

We note that the two filtering methods yield broadly similar results. For GDP we find a lower and a higher cycle frequency. No general pattern as to which of the two frequencies has the largest contribution to the total variance emerges. The high frequency implies cycle lengths ranging from about 21/2 years (Canada; BP-filtered) to about 8 years (Finland; BP-filtered). The average short frequency is 5 years. This is in line with the conventional business cycle 
frequency of up to 8 years (Comin and Gertler, 2006; Borio 2014). The low frequency in GDP ranges from about 51/2 years (United States; BP-filtered) to 15 years (Canada, Finland, and France; first-differenced). On average, we find cycles between 9 and 12 years. This is consistent with the medium-run US business cycle frequency found by Comin and Gertler (2006).

For INTR, we note a relatively high frequency ranging from about $2 \frac{1}{2} 2$ years (Finland; firstdifferenced) to about 61/2 years (Finland; BP-filtered). On average, we find a cycle length of about 3 to 4 years. NFCD exhibits lower frequencies ranging between 61/2 years (Australia; BPfiltered) to 191/2 years (Great Britain; first-differenced). On average, we find a cycle length of 8 to 10 years. Lastly, for $H H D$, we find substantially longer cycle lengths ranging from 10 years (Canada, BP-filtered) to up to 221/2 years (Germany; first-differenced). The average cycle length is between $14 \frac{1}{2}$ and 17 years.

Overall, these findings indicate that real activity as measured by real output exhibits different cycle frequencies of about 5 and 10 years, respectively. We observe a high cycle frequency in short-term real interest rates of around 5 years, and longer debt cycles of about 10 years for business debt, and around 16 years for household debt. We further note that the higher cycle frequency in GDP corresponds closely to the frequency found in INTR. The lower frequency in $G D P$, on the other hand, is closer to the frequency in NFCD rather than $H H D$.

To obtain further visual evidence for these cycle frequencies, we jointly plot each financial variable along with GDP against time, using three different de-trending methods: the HodrickPrescott (HP) filter, the BP filter as before, and quadratic de-trending. Figure 2 depicts the results. Overall, the filters support the findings of the spectral density analysis: INTR, NFCD, and $H H D$ exhibit cycle frequencies of around half a decade, a decade, and about two decades, respectively. GDP exhibits at least two frequencies, of which the higher one appears to be correlated with INTR, whereas the lower frequency seems to correspond to $N F C D$ rather than HHD. 
Figure 2: Filtered series of GDP, INTR, NFCD and $H H D$; 1970-2015

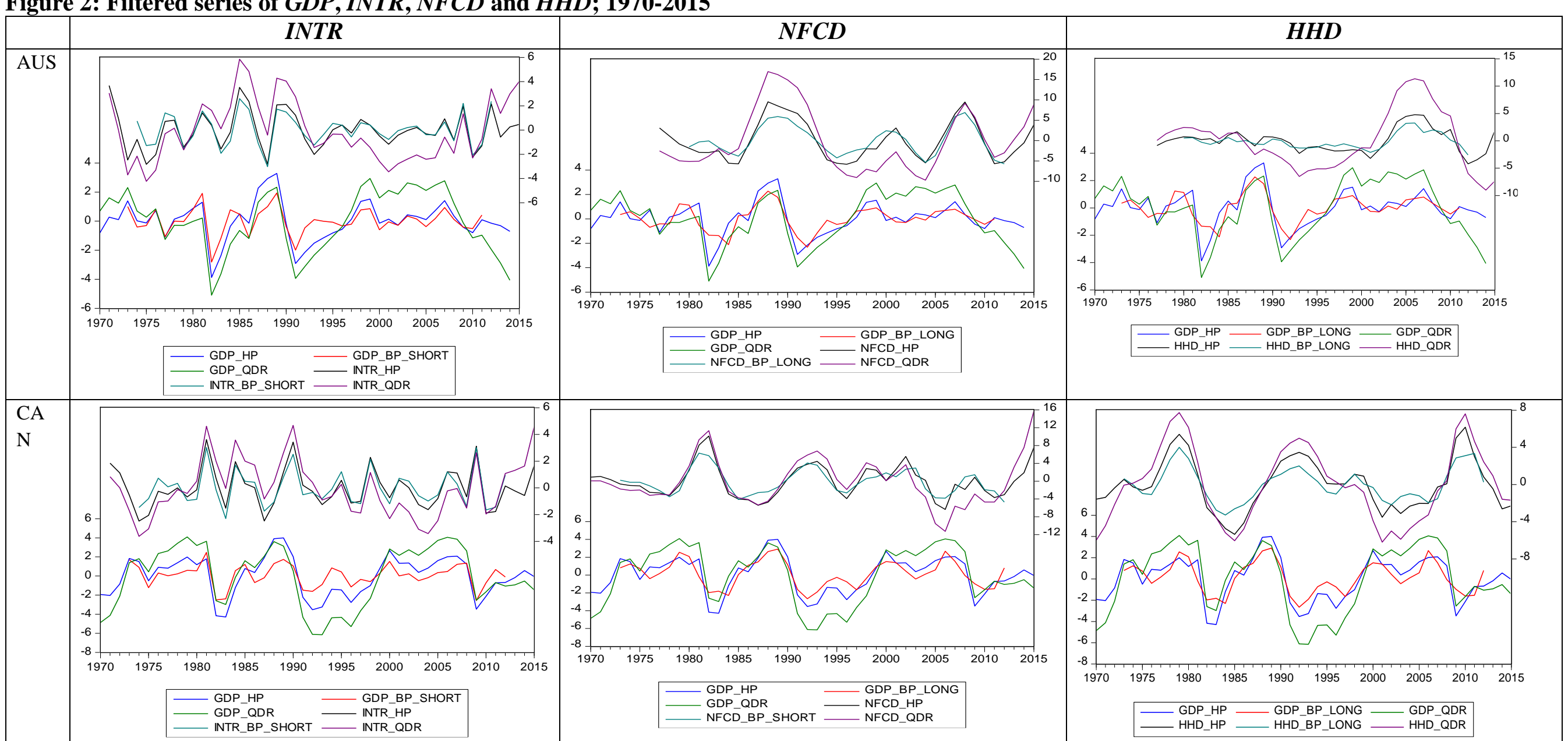




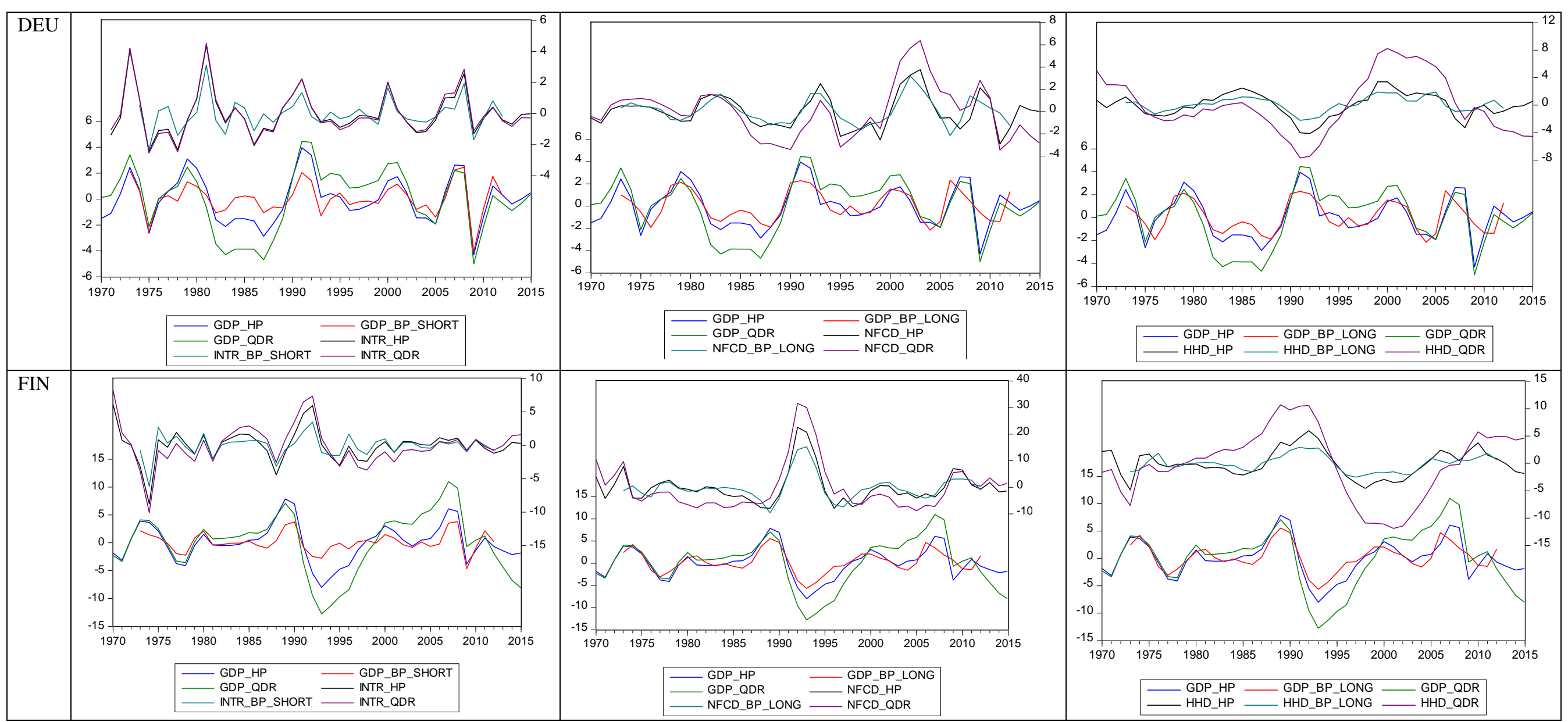




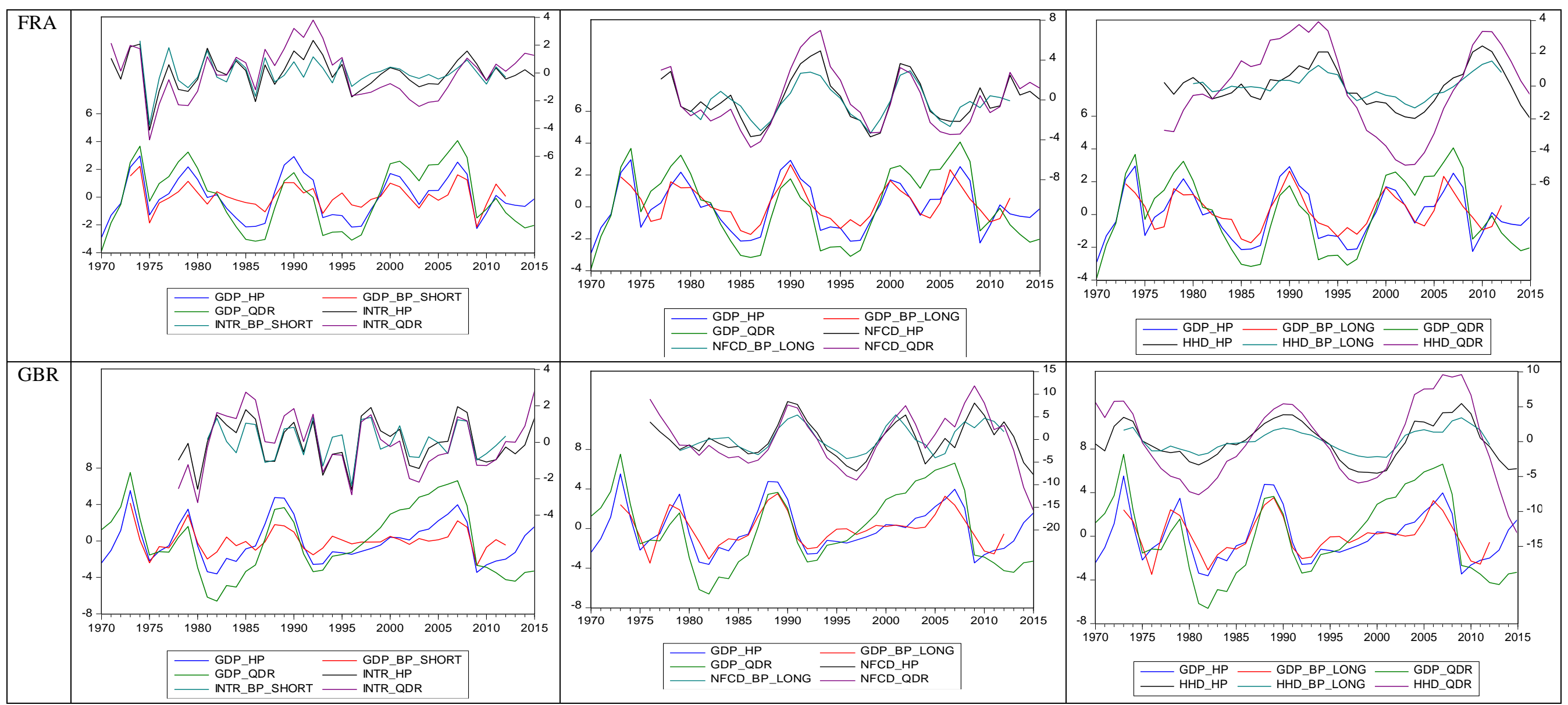



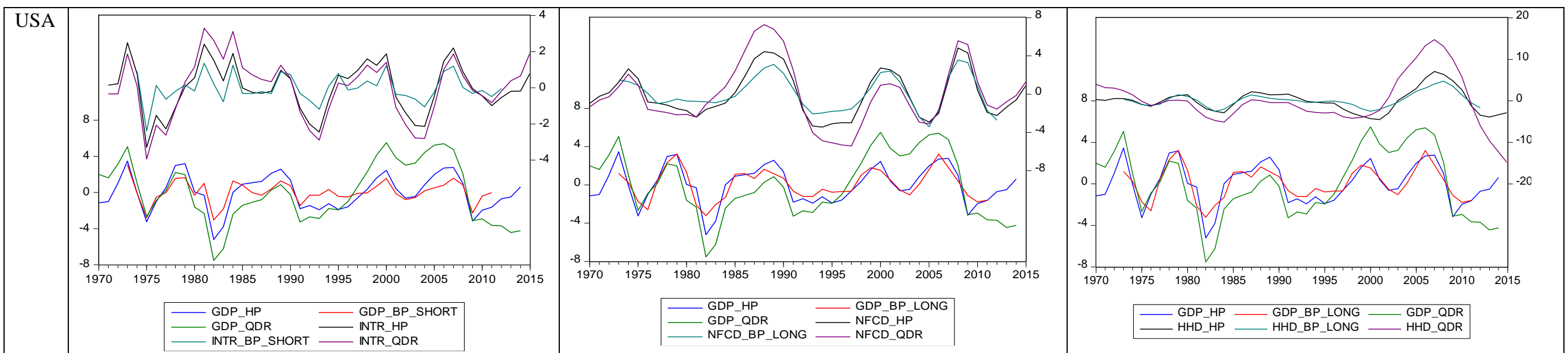

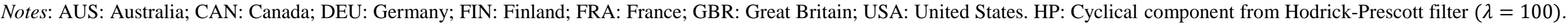

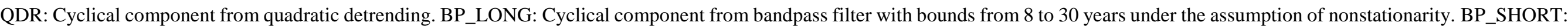

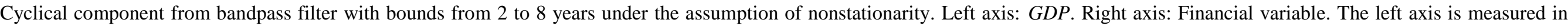
percent deviation from trend, whereas the right axis can be read as percentage-point deviation from trend. 


\section{Estimation results}

The descriptive statistics in section 4 are suggestive of common cycles in GDP and at least a subset of the financial variables under consideration. We now proceed to estimate the empirical system in (5), described in section 3 above. Note that the VAR models are estimated on the data in levels, not the de-trended data used in section 4. Inclusion of level variables is common in the VAR literature. The fact that some variables may be I(1) does not constitute a problem because the slope coefficients on the I(1) variables could be re-written as coefficients on differenced (and thus I(0)) variables (Sims et al., 1990). We also estimated our models with a linear time trend, which did not alter our results significantly.

\subsection{Interaction between GDP and the interest rate}

Table 2 summarises our estimation results for interest rates. ${ }^{8}$ First, we note that the coefficients $\alpha_{2}$ and $\beta_{1}$ exhibit the expected signs in six out of seven countries. In Australia, Canada, Germany, France, Great Britain, and the United States, INTR has a negative effect on GDP, whereas GDP exerts a positive effect on the rate of interest. Thus, the basic cyclical interaction mechanism hypothesised by the financial-real cycle models discussed in section 3 , where the real variable pushes up the financial variable which in turn depresses the real variable, is supported by our findings. In Finland, GDP exerts an unexpected negative effect on INTR, so that there is no evidence for a cycle mechanism.

\footnotetext{
${ }^{8}$ Serial correlations tests (see appendix A2) confirm that all VARs except for France are free from autocorrelation. In the VAR for France, serial correlation did not fully vanish even after including up to six lags. We thus report the baseline specification with two lags, which exhibits third-order autocorrelation.
} 
Table 2: VAR models with GDP and INTR

\begin{tabular}{|c|c|c|c|c|c|c|c|c|}
\hline Country & DV & EPV & Coeff LDV & Coeff EPV & $\begin{array}{l}\text { Lag } \\
\text { order }\end{array}$ & $\begin{array}{l}\text { Necessary } \\
\text { condition } \\
\text { satisfied? }\end{array}$ & Sample & $\begin{array}{l}\text { Cycle } \\
\text { length }\end{array}$ \\
\hline \multirow[t]{2}{*}{ AUS } & $G D P$ & INTR & $\begin{array}{l}1.040 \\
(0.151)^{* * *}\end{array}$ & $\begin{array}{l}-0.234 \\
(0.112)^{* *}\end{array}$ & \multirow[t]{2}{*}{2} & \multirow[t]{2}{*}{ yes } & \multirow[t]{2}{*}{$\begin{array}{l}1973- \\
2015\end{array}$} & \multirow[t]{2}{*}{3.91} \\
\hline & INTR & $G D P$ & $\begin{array}{l}0.799 \\
(0.153)^{* * *}\end{array}$ & $\begin{array}{l}0.369 \\
(0.206)^{*}\end{array}$ & & & & \\
\hline \multirow[t]{2}{*}{ CAN } & $G D P$ & INTR & $\begin{array}{l}1.176 \\
(0.159)^{* * *}\end{array}$ & $\begin{array}{l}-0.262 \\
(0.158)\end{array}$ & \multirow[t]{2}{*}{2} & \multirow[t]{2}{*}{ yes } & \multirow[t]{2}{*}{$\begin{array}{l}1973- \\
2015\end{array}$} & \multirow[t]{2}{*}{$\begin{array}{l}\text { No complex } \\
\text { eigenvalue }\end{array}$} \\
\hline & INTR & $G D P$ & $\begin{array}{l}0.666 \\
(0.159)^{* * *}\end{array}$ & $\begin{array}{l}0.177 \\
(0.160)\end{array}$ & & & & \\
\hline \multirow[t]{2}{*}{ DEU } & $G D P$ & INTR & $\begin{array}{l}1.231 \\
(0.192)^{* * *}\end{array}$ & $\begin{array}{l}-0.362 \\
(0.225)\end{array}$ & \multirow[t]{2}{*}{3} & \multirow[t]{2}{*}{ yes } & \multirow[t]{2}{*}{$\begin{array}{l}1973- \\
2015\end{array}$} & \multirow[t]{2}{*}{$\begin{array}{l}4.59 \\
3.53\end{array}$} \\
\hline & INTR & GDP & $\begin{array}{l}0.607 \\
(0.188)\end{array}$ & $\begin{array}{l}0.121 \\
(0.160)\end{array}$ & & & & \\
\hline \multirow[t]{2}{*}{ FIN } & $G D P$ & INTR & $\begin{array}{l}1.369 \\
(0.141)^{* * *}\end{array}$ & $\begin{array}{l}-0.299 \\
(0.159)^{*}\end{array}$ & \multirow[t]{2}{*}{3} & \multirow[t]{2}{*}{ no } & \multirow[t]{2}{*}{$\begin{array}{l}1972- \\
2015\end{array}$} & \multirow[t]{2}{*}{$\begin{array}{c}\text { No complex } \\
\text { eigenvalue }\end{array}$} \\
\hline & INTR & GDP & $\begin{array}{l}0.748 \\
(0.155)^{* * *}\end{array}$ & $\begin{array}{l}-0.092 \\
(0.137)\end{array}$ & & & & \\
\hline \multirow[t]{2}{*}{ FRA } & $G D P$ & INTR & $\begin{array}{l}1.268 \\
(0.165)^{* * *}\end{array}$ & $\begin{array}{l}-0.270 \\
(0.151)^{*}\end{array}$ & \multirow[t]{2}{*}{2} & \multirow[t]{2}{*}{ yes } & \multirow[t]{2}{*}{$\begin{array}{l}1973- \\
2015\end{array}$} & \multirow[t]{2}{*}{$\begin{array}{c}\text { No complex } \\
\text { eigenvalue }\end{array}$} \\
\hline & INTR & GDP & $\begin{array}{l}0.625 \\
(0.166)^{* * *}\end{array}$ & $\begin{array}{l}0.124 \\
(0.180)\end{array}$ & & & & \\
\hline \multirow[t]{2}{*}{ GBR } & $G D P$ & INTR & $\begin{array}{l}1.600 \\
(0.161)^{* * *}\end{array}$ & $\begin{array}{l}-0.302 \\
(0.202)\end{array}$ & \multirow[t]{2}{*}{3} & \multirow[t]{2}{*}{ yes } & \multirow[t]{2}{*}{$\begin{array}{l}1981- \\
2015\end{array}$} & \multirow[t]{2}{*}{$\begin{array}{l}5.96 ; \\
3.45\end{array}$} \\
\hline & INTR & GDP & $\begin{array}{l}0.426 \\
(0.158)^{* *}\end{array}$ & $\begin{array}{l}0.060 \\
(0.126)\end{array}$ & & & & \\
\hline \multirow[t]{2}{*}{ USA } & $G D P$ & INTR & $\begin{array}{l}1.472 \\
(0.164)^{* * *}\end{array}$ & $\begin{array}{l}-0.719 \\
(0.253)^{* * *}\end{array}$ & \multirow[t]{2}{*}{2} & \multirow[t]{2}{*}{ yes } & \multirow[t]{2}{*}{$\begin{array}{l}1973- \\
2014\end{array}$} & \multirow[t]{2}{*}{7.29} \\
\hline & INTR & $G D P$ & $\begin{array}{l}0.856 \\
(0.180)^{* * *}\end{array}$ & $\begin{array}{l}0.130 \\
(0.117)\end{array}$ & & & & \\
\hline \multirow{2}{*}{$\begin{array}{l}\text { Avr. cycle } \\
\text { length }\end{array}$} & With & 11 eigen & alues & & & & & 4.79 \\
\hline & Only & ith long & er length & & & & & 5.44 \\
\hline
\end{tabular}

Notes: AUS: Australia; CAN: Canada; DEU: Germany; FIN: Finland; FRA: France; GBR: Great Britain; USA: United States. DVL: Dependent variable. LDV: First lagged dependent variable. EPV: First lag of explanatory variable. Standard errors in parentheses. *, **,*** denote statistical significance at the 1,5 , and $10 \%$-level, respectively. Necessary condition: $\alpha_{2} \beta_{1}<0$. All specifications were estimated with a constant (not reported). 
While the estimated coefficients $\alpha_{2}$ and $\beta_{1}$ exhibit the expected signs in six out of seven countries, recursive parameter estimation - i.e. estimating the VAR models on a sample that is recursively increased by one observation at a time - indicates parameter instability in four of the six countries in which the expected sign structure exists. In fact, the only countries with stable $\alpha_{2}$ and $\beta_{1}$ coefficients are Australia and the USA. This is illustrated in Figure 3, which plots the recursively estimated $\alpha_{2}$ and $\beta_{1}$ coefficients for Australia and the USA. It is also worth noting that only in Australia are both $\alpha_{2}$ and $\beta_{1}$ statistically significant at conventional levels. In the United States, by contrast, only $\alpha_{2}$ is statistically significant. 
Figure 3: Recursive estimates of $\alpha_{2}$ and $\beta_{1}$ for Australia (top panel) and USA (bottom panel), interest rate models

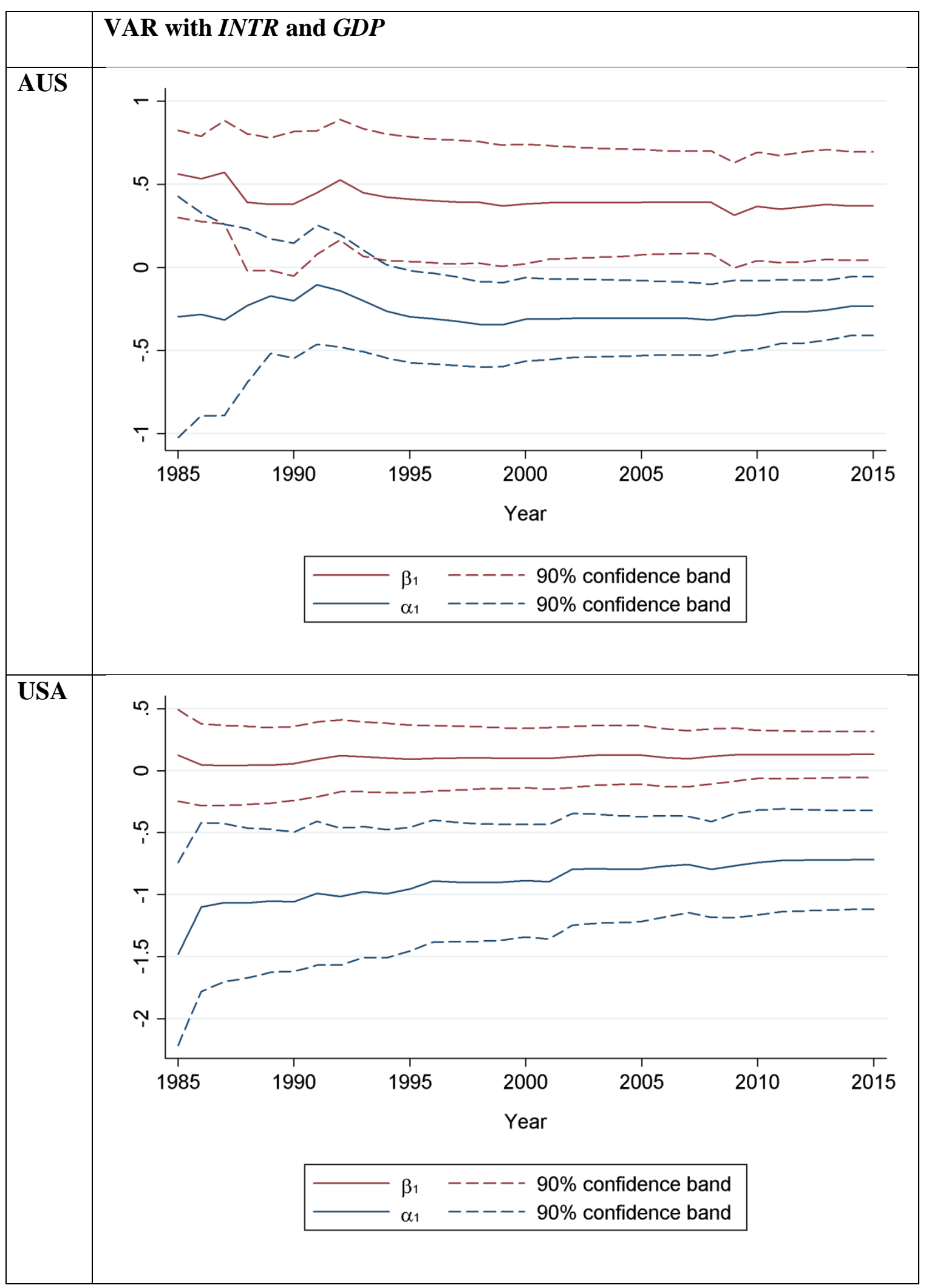


Looking at the cycle length implied by the eigenvalues of the estimated coefficient matrix, we find that the cycle length for Australia is just shy of four years, and the cycle length for the USA is just over seven years. This is very close to the cycle lengths obtained from the spectral density functions reported in Table 1 for Australia, and slightly longer than the cycle length for the USA. Overall, the results provide support for the existence of a stable financial-real interaction mechanism in output and the real interest rate for Australia and the USA.

\subsection{Interaction between GDP and corporate debt}

The results of our estimations with corporate debt are depicted in Table $3 .{ }^{9}$ We find that all countries except Finland exhibit the sign structure predicted by financial-real cycle theories: $N F C D$ exerts a negative effect on GDP, while GDP in turn raises NFCD. Again, however, several VARs suffer from at least some structural instability, as indicated by recursive parameter estimates. The two countries with relatively stable parameter estimates are Canada and the Great Britain. While the recursive estimates of $\alpha_{2}$ and $\beta_{1}$ for Canada decrease in magnitude as the sample size is increased, they retain the expected signs. The recursive estimates of $\alpha_{2}$ and $\beta_{1}$ for the Great Britain switch signs around 1990, but remain stable thereafter, as illustrated in Figure 4.

\footnotetext{
${ }^{9}$ Serial correlation tests (see appendix A2) confirmed that all VARs are free of serial correlation.
} 
Table 3: VAR models with GDP and NFCD

\begin{tabular}{|c|c|c|c|c|c|c|c|c|}
\hline Country & DV & EPV & Coeff LDV & Coeff EPV & $\begin{array}{l}\text { Lag } \\
\text { order }\end{array}$ & $\begin{array}{l}\text { Necessary } \\
\text { condition } \\
\text { satisfied? }\end{array}$ & Period & $\begin{array}{l}\text { Cycle } \\
\text { length }\end{array}$ \\
\hline \multirow[t]{2}{*}{ AUS } & $G D P$ & $N F C D$ & $\begin{array}{c}1.097 \\
(0.179)^{* * *}\end{array}$ & $\begin{array}{l}-0.003 \\
(0.077)\end{array}$ & 2 & \multirow[t]{2}{*}{ Yes } & \multirow[t]{2}{*}{$\begin{array}{l}1979- \\
2014\end{array}$} & \multirow[t]{2}{*}{15.15} \\
\hline & NFCD & $G D P$ & $\begin{array}{c}1.554 \\
(0.120)^{* * *}\end{array}$ & $\begin{array}{c}0.117 \\
(0.279)^{* * *}\end{array}$ & & & & \\
\hline \multirow[t]{2}{*}{ CAN } & $G D P$ & $N F C D$ & $\begin{array}{c}1.127 \\
(0.157)^{* * *}\end{array}$ & $\begin{array}{c}-0.188 \\
(0.102)^{*}\end{array}$ & 2 & Yes & \multirow[t]{2}{*}{$\begin{array}{l}1972- \\
2015\end{array}$} & \multirow[t]{2}{*}{13.09} \\
\hline & NFCD & $G D P$ & $\begin{array}{c}1.413 \\
(0.155)^{* * *}\end{array}$ & $\begin{array}{c}0.381 \\
(0.239)\end{array}$ & & & & \\
\hline \multirow[t]{2}{*}{ DEU } & $G D P$ & NFCD & $\begin{array}{c}1.065 \\
(0.165)^{* * *}\end{array}$ & $\begin{array}{l}-0.103 \\
(0.238)\end{array}$ & 3 & Yes & \multirow[t]{2}{*}{$\begin{array}{l}1973- \\
2015\end{array}$} & \multirow[t]{2}{*}{$\begin{array}{l}7.00 ; \\
3.52\end{array}$} \\
\hline & NFCD & $G D P$ & $\begin{array}{c}1.153 \\
(0.147)^{* * *}\end{array}$ & $\begin{array}{c}0.058 \\
(0.101)^{* * *}\end{array}$ & & & & \\
\hline \multirow[t]{2}{*}{ FIN } & $G D P$ & $N F C D$ & $\begin{array}{c}1.297 \\
(0.163)^{* * *}\end{array}$ & $\begin{array}{l}-0.121 \\
(0.092)\end{array}$ & 2 & No & \multirow[t]{2}{*}{$\begin{array}{l}1972- \\
2015\end{array}$} & \multirow[t]{2}{*}{13.38} \\
\hline & NFCD & $G D P$ & $\begin{array}{c}0.946 \\
(0.149)^{* * *}\end{array}$ & $\begin{array}{c}-0.705 \\
(0.263)^{* *}\end{array}$ & & & & \\
\hline \multirow[t]{2}{*}{ FRA } & $G D P$ & $N F C D$ & $\begin{array}{c}1.226 \\
(0.172)^{* * *}\end{array}$ & $\begin{array}{l}-0.085 \\
(0.117)\end{array}$ & 2 & Yes & \multirow[t]{2}{*}{$\begin{array}{l}1979- \\
2015\end{array}$} & \multirow[t]{2}{*}{181.24} \\
\hline & NFCD & $G D P$ & $\begin{array}{c}1.318 \\
(0.149)^{* * *}\end{array}$ & $\begin{array}{c}0.673 \\
(0.220)^{* * *}\end{array}$ & & & & \\
\hline \multirow[t]{2}{*}{ GBR } & $G D P$ & $N F C D$ & $\begin{array}{c}1.427 \\
(0.169)^{* * *}\end{array}$ & $\begin{array}{l}-0.038 \\
(0.106)\end{array}$ & 2 & Yes & \multirow[t]{2}{*}{$\begin{array}{l}1978- \\
2015\end{array}$} & \multirow[t]{2}{*}{8.77} \\
\hline & $N F C D$ & $G D P$ & $\begin{array}{c}1.191 \\
(0.158)^{* * *}\end{array}$ & $\begin{array}{c}0.231 \\
(0.252)\end{array}$ & & & & \\
\hline \multirow[t]{2}{*}{ USA } & $G D P$ & NFCD & $\begin{array}{c}1.251 \\
(0.166)^{* * *}\end{array}$ & $\begin{array}{c}-0.170 \\
(0.346)^{* * *}\end{array}$ & 3 & Yes & \multirow[t]{2}{*}{$\begin{array}{l}1972- \\
2015\end{array}$} & \multirow[t]{2}{*}{$\begin{array}{l}9.29 \\
5.19\end{array}$} \\
\hline & $N F C D$ & $G D P$ & $\begin{array}{c}1.938 \\
(0.149)^{* * *}\end{array}$ & $\begin{array}{c}0.315 \\
(0.072)\end{array}$ & & & & \\
\hline $\begin{array}{l}\text { Avr. cycle } \\
\text { length }\end{array}$ & & & & & & & & 11.11 \\
\hline
\end{tabular}

Notes: AUS: Australia; CAN: Canada; DEU: Germany; FIN: Finland; FRA: France; GBR: Great Britain; USA: United States. DVL: Dependent variable. LDV: First lagged dependent variable. EPV: First lag of explanatory variable. Standard errors in parentheses. *, **,*** denote statistical significance at the 1,5 , and $10 \%$-level, respectively. Necessary condition: $\alpha_{2} \beta_{1}<0$. All specifications were estimated with a constant (not reported). For the average cycle length, we excluded the outlier France and used the longer cycle period, when the system has more than one complex eigenvalue. 
Thus we find evidence of a stable financial-real interaction mechanism in output and corporate debt for Canada and the Great Britain. This constitutes evidence in favour of the Minskyan and financial accelerator theories for these countries. It is worth noting that only in Finland does $G D P$ appear to have a negative effect on corporate debt as discussed by the paradox of debt literature (Lavoie and Seccareccia, 2001). If we return to the time series chart for Finland in Figure 2, this finding is perhaps not overly surprising, as the relationship between $N F C D$ and $G D P$ appears to be dominated by the large negative shock to GDP, and associated rise in corporate leverage ratios, observed during the Finnish banking crisis of the early 1990s. 
Figure 4: Recursive estimates of $\alpha_{2}$ and $\beta_{1}$ for Canada (top panel) and Great Britain (bottom panel), corporate debt models

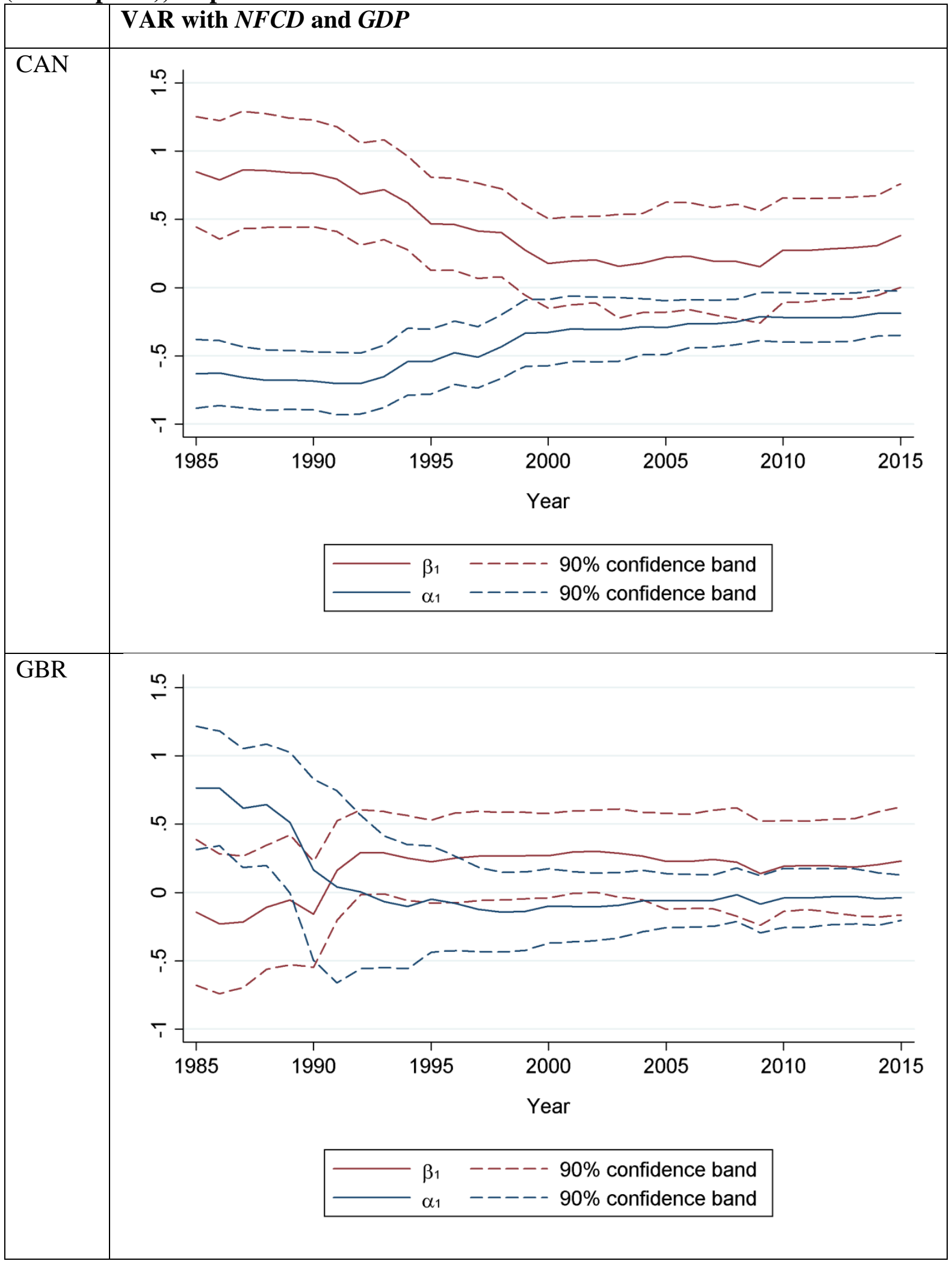

Looking at the cycle length implied by the eigenvalues of the estimated coefficient matrix, we find that the cycle length for Canada is just over 13 years, and the cycle length for the Great 
Britain is just shy of nine years. This is very close to the cycle length reported in Table 1 for the Great Britain using the BP filter, and slightly longer than the cycle lengths for Canada. Overall, the results provide support for the existence of a stable financial-real interaction mechanism in output and corporate debt for Canada and the Great Britain.

\subsection{Interaction between GDP and household debt}

Finally, Table 4 presents the results for household debt. ${ }^{10}$ First, we note that $H H D$ exerts a positive effect on GDP in all countries, which is inconsistent with the sign predicted by the financial-real cycle models discussed in section 3. This can arise if households are credit constrained. We further find negative effects of GDP on $H H D$ in four countries (Canada, Germany, Finland and France). Although the necessary condition for a cycle mechanism is formally satisfied in Canada, Germany, Finland, and France, it contradicts the structure of the financial-real cycle model in (1). In Australia, Great Britain, and the United States, by contrast, the condition for a cycle mechanism is not satisfied as the coefficients on the explanatory variables are positive in both equations. In addition, recursive parameter estimates suggest that parameters in many of the models with $H H D$ are unstable. Overall, we conclude that there is no evidence for the existence of a financial-real cycle mechanism between $H H D$ and GDP of the type considered in section 2 above. This is consistent with the cycle lengths presented in Table 1, where the dominant cycle in household debt is much longer than the cycles in GDP for the majority of the countries under investigation.

${ }^{10}$ Serial correlation tests (see Table A6 in the online appendix) showed that all VARs are free of serial correlation. 
Table 4: VAR models with GDP and $H H D$

\begin{tabular}{|c|c|c|c|c|c|c|c|c|}
\hline Country & DV & EPV & Coeff LDV & Coeff EPV & $\begin{array}{l}\text { Lag } \\
\text { order }\end{array}$ & $\begin{array}{l}\text { Necessary } \\
\text { condition } \\
\text { satisfied? }\end{array}$ & Period & Cycle length \\
\hline \multirow[t]{2}{*}{ AUS } & $G D P$ & $H H D$ & $\begin{array}{c}1.089 \\
(0.179)^{* * *}\end{array}$ & $\begin{array}{l}0.030 \\
(0.145)\end{array}$ & 2 & No & \multirow[t]{2}{*}{$\begin{array}{l}1979- \\
2014\end{array}$} & \multirow[t]{2}{*}{$\begin{array}{l}\text { No complex } \\
\text { eigenvalue }\end{array}$} \\
\hline & $H H D$ & GDP & $\begin{array}{c}1.485 \\
(0.142)^{* * *}\end{array}$ & $\begin{array}{c}0.135 \\
(0.175)\end{array}$ & & & & \\
\hline \multirow[t]{2}{*}{ CAN } & $G D P$ & $H H D$ & $\begin{array}{c}1.331 \\
(0.154)^{* * *}\end{array}$ & $\begin{array}{c}0.393 \\
(0.194)^{*}\end{array}$ & 3 & Yes & \multirow[t]{2}{*}{$\begin{array}{l}1973- \\
2015\end{array}$} & \multirow[t]{2}{*}{$\begin{array}{c}17.70 \\
3.60\end{array}$} \\
\hline & $H H D$ & $G D P$ & $\begin{array}{c}1.617 \\
(0.161)^{* * *}\end{array}$ & $\begin{array}{l}-0.115 \\
(0.128)\end{array}$ & & & & \\
\hline \multirow[t]{2}{*}{ DEU } & $G D P$ & $H H D$ & $\begin{array}{c}1.114 \\
(0.166)^{* * *}\end{array}$ & $\begin{array}{c}0.142 \\
(0.206)\end{array}$ & 2 & Yes & \multirow[t]{2}{*}{$\begin{array}{l}1972- \\
2015\end{array}$} & \multirow[t]{2}{*}{49.21} \\
\hline & $H H D$ & $G D P$ & $\begin{array}{c}1.583 \\
(0.129)^{* * *}\end{array}$ & $\begin{array}{l}-0.058 \\
(0.104)\end{array}$ & & & & \\
\hline \multirow[t]{2}{*}{ FIN } & $G D P$ & $H H D$ & $\begin{array}{c}1.313 \\
(0.164)^{* * *}\end{array}$ & $\begin{array}{c}0.273 \\
(0.224)\end{array}$ & 4 & Yes & \multirow[t]{2}{*}{$\begin{array}{l}1974- \\
2015\end{array}$} & $\begin{array}{c}25.99 \\
6.15\end{array}$ \\
\hline & $H H D$ & $G D P$ & $\begin{array}{c}1.445 \\
(0.155)^{* * *}\end{array}$ & $\begin{array}{l}-0.006 \\
(0.113)\end{array}$ & & & & 3.47 \\
\hline \multirow[t]{2}{*}{ FRA } & $G D P$ & $H H D$ & $\begin{array}{c}1.401 \\
(0.168)^{* * *}\end{array}$ & $\begin{array}{c}0.485 \\
(0.300)\end{array}$ & 3 & Yes & \multirow[t]{2}{*}{$\begin{array}{l}1980- \\
2015\end{array}$} & \multirow[t]{2}{*}{$\begin{array}{c}26.32 \\
4.64\end{array}$} \\
\hline & $H H D$ & GDP & $\begin{array}{c}1.515 \\
(0.180)^{* * *}\end{array}$ & $\begin{array}{c}-0.042 \\
(0.101)^{* * *}\end{array}$ & & & & \\
\hline \multirow[t]{2}{*}{ GBR } & $G D P$ & $H H D$ & $\begin{array}{c}1.345 \\
(0.147)^{* * *}\end{array}$ & $\begin{array}{c}0.052 \\
(0.275)\end{array}$ & 4 & No & \multirow[t]{2}{*}{$\begin{array}{l}1974- \\
2015\end{array}$} & $\begin{array}{l}17.99 \\
5.12\end{array}$ \\
\hline & $H H D$ & $G D P$ & $\begin{array}{c}1.443 \\
(0.132)^{* * *}\end{array}$ & $\begin{array}{c}0.194 \\
(0.097)^{*}\end{array}$ & & & & 2.67 \\
\hline \multirow[t]{2}{*}{ USA } & $G D P$ & $H H D$ & $\begin{array}{c}1.076 \\
(0.163)^{* * *}\end{array}$ & $\begin{array}{c}0.639 \\
(0.308)^{* * *}\end{array}$ & 4 & No & \multirow[t]{2}{*}{$\begin{array}{l}1974- \\
2015\end{array}$} & $\begin{array}{l}19.34 \\
5.91\end{array}$ \\
\hline & $H H D$ & $G D P$ & $\begin{array}{c}1.996 \\
(0.161)^{* * *}\end{array}$ & $\begin{array}{c}0.076 \\
(0.085)\end{array}$ & & & & 3.50 \\
\hline $\begin{array}{l}\text { Avr. cycle } \\
\text { length }\end{array}$ & & & & & & & & $\begin{array}{l}26.09 ; \\
21.47 \text { (w/o DEU) }\end{array}$ \\
\hline
\end{tabular}

Notes: AUS: Australia; CAN: Canada; DEU: Germany; FIN: Finland; FRA: France; GBR: Great Britain; USA: United States. DVL: Dependent variable. LDV: First lagged dependent variable. EPV: First lag of explanatory variable. Standard errors in parentheses. *, **,*** denote statistical significance at the 1,5 , and $10 \%$-level, respectively. Necessary condition: $\alpha_{2} \beta_{1}<0$. All specifications were estimated with a constant (not reported). For the average cycle length, we use the longest implied cycle length of each country. 


\subsection{Robustness tests}

To assess the robustness of our estimations with $N F C D$ and $H H D$, we replace the denominator in the debt to income ratios with the net capital stock. The resulting alternative measures are denoted $N F C D^{C P S T}$ and $H H D^{C P S T}$, respectively. ${ }^{11}$ We thereby account for the possibility that the estimated relationship between debt-to-income ratios and lagged GDP is affected by the presence of contemporary GDP in the denominator. The estimation results are presented in Table A9 in the appendix. The results with $N F C D^{C S T}$ are very similar to our baseline results. The only country where the sign structure changes compared to the main estimation results is Australia, where the necessary condition for a cycle mechanism is no longer satisfied. However, as noted above, the cycle mechanism in debt and GDP for Australia was not found to be stable. In contrast, the results with $H H D^{C S T}$ (see Table A10) exhibit strong differences compared to the baseline, with five countries exhibiting changes in the signs of the point estimates. Overall, the estimations with $H H D$ lack robustness.

As a further robustness check, we re-estimate the VARs with the growth rate (log-difference) of corporate debt and household debt, respectively. The results are reported in Table A11 and A12 in the online appendix. With corporate debt $\left(N F C D^{D L O G}\right)$, we find the expected signs in Canada, France, Finland, Great Britain, and the United States. Only Australia and Germany do not meet the necessary condition for a cycle mechanism compared to the baseline, but again, these results were not found to be stable in section 5.2. Finland, which did not meet the necessary condition for a cycle mechanism in the baseline estimates, now exhibits the sign structure predicted by theories of financial-real cycles. Overall, we do not find evidence for a systematic difference in the interaction between output and the stock versus the flow of corporate debt. With household debt $\left(H H D^{D L O G}\right)$ the results again differ strongly compared to the baseline. Only Germany and Finland retain the sign structure of the baseline, whereas all other countries change signs. As no clear-cut pattern emerges, these results do not point to a systematic difference in the behaviour of the flow versus the stock of household debt. Instead, they reinforce the conclusion that the estimation results with $H H D$ are not robust.

\footnotetext{
${ }^{11}$ We use the total net capital stock as sector-specific alternatives such as the business sector and residential capital stock are not available for the full period under consideration.
} 


\subsection{Summary of baseline results}

Our results indicate the existence of stable financial-real cycles in the real interest rate and GDP for Australia and the USA, and corporate debt and GDP for Canada and the Great Britain. A number of other countries display the necessary conditions for financial-real cycles, but these mechanisms appear to be unstable over time. Notably, we find evidence of a stable financialreal interaction mechanism for each of the English-speaking countries, and no robust evidence of a financial-real interaction mechanism for the continental European economies in our sample. We note that the former have been classified as market-based financial systems and the latter as bank-based financial systems by Demirgüc-Kunt and Levine (1999). These results indicate that a comparative investigation of the financial cycles in English-speaking and continental European economies is an interesting avenue for future research.

Finally, our baseline results indicate the complete absence of a financial-real cycle mechanism between household debt and GDP of the kind discussed in section 3. Moreover, recursive parameter estimation and further robustness tests suggest a lack of robustness of these results, so that the unexpected signs in the baseline estimations cannot be interpreted as evidence for counterarguments to the financial-real cycle mechanism such as credit-constraints or a paradox of debt. We therefore conjecture that household debt interacts with aggregate output in a more complicated manner than that captured by the simple reduced form model in (1).

\section{Further results: Which components of output matter?}

In order to investigate which components of GDP matter in the financial-real interaction mechanisms examined above, we re-estimate our models with two subcomponents of total output: investment and consumption. For the INTR models, we use total investment (INV), as well as consumption (CONS). For the NFCD models, we use total investment. Lastly, for the $H H D$ models, we use consumption as well as residential investment (INV_RES). The estimation results are reported in online appendix A5.

Using $I N V$ instead of GDP in the estimations with $I N T R$, we find the necessary condition for a financial-real interaction mechanism is satisfied in all countries (see Table A13). Recursive estimation suggests parameter stability in five of seven countries (Canada, Germany, Finland, France and USA; see Figure A1). Using CONS instead of GDP in the estimations with INTR, we find the necessary condition for a financial-real interaction mechanism satisfied in all 
countries except Australia (see Table A14), but parameters are stable only for Germany and the USA (see Figure A2). In the estimations with $I N V$, the average implied cycle length for Canada, Germany, and the USA is around 7 years, i.e. similar to the baseline estimations. ${ }^{12}$ With CONS, the implied cycle length for Germany is an outlier, whereas the US exhibits a low frequency of $24 \frac{1}{2}$ years and a high frequency of 5 years. Overall, we find stronger evidence for a short-run interaction mechanism between INTR and INV rather than CONS.

When using $I N V$ instead of $G D P$ in the estimations with $N F C D$, we find the necessary condition satisfied in all countries except Australia and Finland (see Table A15). The results for Canada, Britain and the USA are stable in recursive estimations (see Figure A3). The estimated average cycle lengths of those countries ${ }^{13}$ of 11 years (with INV) strongly correspond to the frequencies obtained in the main estimations. Overall, the estimations suggest that the interaction mechanism between $N F C D$ and GDP is largely governed by the investment component of GDP.

Lastly, re-estimation of the system with $H H D$ and CONS leads to a mixed picture. It yields qualitatively different findings from our baseline for each country except Canada (see Table A16). We find the expected signs of the financial-real cycle model in four countries, but only for the USA the results are stable in recursive estimation (see Figure A5). The estimation with the USA suggests a cycle length of 19 years. We also experimented with $I N V \_R E S$ instead of $G D P$, the results are similar to the baseline estimations (see Table A17). Only for Canada do we find the necessary condition for a financial-real cycle satisfied with expected signs, but the estimated parameters are structurally unstable. In sum, we fail to find robust evidence for a financial-real cycle mechanism between $H H D$ and CONS or INV_RES (with the exception of the USA for $H H D$ and $C O N S$ ).

\section{Conclusions}

\footnotetext{
12 The implied cycle length of Finland is an outlier and was thus excluded. The VAR for Great Britain does not exhibit complex eigenvalues.

${ }^{13}$ Several specifications of the robustness estimations required a lag order of more than two, which often yielded multiple eigenvalues. In order to calculate the average cycle length, we chose the eigenvalue being closest to the average cycle length found in the spectral density functions.
} 
In this paper, we have presented empirical evidence for theories of financial-real cycles that arise from the endogenous interaction of financial and real variables. We find that output exhibits a short-run cycle frequency of about 4-5 years and a medium-run frequency of 9-12 years. Interest rates exhibit short cycles lengths of about 4-5, business debt a medium-run length of 8-11 years, and household debt exhibits long cycles of 14-26 years. We provide evidence for stable interaction mechanisms between short-term real interest rates and GDP in Australia and the United States, and between corporate debt and GDP in Canada and the Great Britain. We further find robust evidence for an interaction mechanism between interest rates and investment and between corporate debt and investment in several countries, suggesting that the interest rate-output mechanism seems to operate via investment rather than consumption In contrast, there is no robust evidence of a financial-real interaction mechanism in Germany, Finland, or France, and no evidence of an interaction mechanism between household debt and GDP in the full sample.

Our findings have interesting theoretical implications. They provide qualified support to theories of financially driven business cycles and they shed further light on the relevant financial variables. Our results lend support to models in which real activity interacts with interest rates (Foley, 1987; Fazzari et al., 2008) as well as to models in which the main cycle mechanism is between business debt and output (Kiyotaki and Moore, 1997; Asada, 2001). Financial factors seem to be important in explaining business cycle fluctuations, but evidence is uneven across countries. This suggests that financial mechanisms are only part of the explanation and other factors are in play, in particular in the continental European countries.

Our results also have noteworthy empirical implications. The stylized fact that financial cycles are longer than business cycles (Drehmann et al., 2012; Borio, 2014; Aikman et al., 2015; Strohsal et al., 2015) has to be amended. Different financial variables exhibit different cycle frequencies. While interest rates exhibit a short-run frequency in line with conventional business cycles frequencies, business debt has a medium-run frequency that matches the medium-run frequency found in output. Only household debt exhibits a frequency that is significantly lower than the medium-run frequency in output. Therefore, it is important to distinguish between different measures of the financial cycle, and in particular to disaggregate total credit into corporate and household debt. 
Our negative findings for household debt might appear surprising given that it was household debt, rather than business debt, that was at the heart of the Global Financial Crisis, and that Jordà et al. (2017) find that higher household debt leads to deeper recessions. However, while our results suggest that there is no interaction mechanism between total output and household debt, they do not imply that household debt does not play a role in the business cycle. Our findings are not inconsistent with the claim that the level of household debt amplifies the depth of downturns, but question whether household debt-output interaction is the source of the business cycle.

This paper is a first attempt to test simple reduced-forms where financial-real interactions give rise to cyclical dynamics. This is part of a research agenda that regards business cycles as resulting from the endogenous interactions of variables rather than exogenous shocks. We see three important areas for future research. First, it should consider richer models that explicate the behavioural equations. Second, our model does not cover asset prices. Given the empirical finding of an important role of house prices during the business cycle (Igan et al., 2011), future research should integrate house prices into a financial-real cycle model with household debt. Lastly, given that previous studies have found a positive link between investment volatility and the size of the stock market (Bezooijen and Bikker, 2017), our finding that the financial-real cycle mechanism is confined to countries with market-based financial systems points to the importance of different financial structures for financial-real cycles. Future research should try to identify which features of national financial systems lead to more pronounced cycles. 


\section{References}

Aikman, D., Haldane, A. G. and Nelson, B. D. (2015) 'Curbing the Credit Cycle', The Economic Journal, 125, 1072-1109.

Arcand, J. L., Berkes, E. and Panizza, U. (2015) 'Too Much Finance?', Journal of Economic Growth, 20, 105-148.

Asada, T. (2001) 'Nonlinear Dynamics of Debt and Capital: A Post-Keynesian Analysis'. In Aruka, Y. (ed) Evolutionary Controversies in Economics. A New Transdisciplinary Approach, Tokyo, Springer Japan, pp. 73-88.

Bernanke, B. S., Gertler, M. and Gilchrist, S. (1999) 'The Financial Accelerator in a Quantitative Business Cycle Framework'. In Taylor, J. B. and Woodford, M. (eds) Handbook of Macroeconomics, pp. 1341-1392.

Bezooijen, E. F. S. and Bikker, J. A. (2017) Financial Structure and Macroeconomic Volatility. A Panel Data Analysis, Utrecht University Discussion Paper Series 17-13, Utrecht, School of Economics Utrecht University.

Biggs, M., Mayer, T. and Pick, A. (2009) Credit and Economic Recovery, DNB Working Paper No. 218, Amsterdam, De Nederlandsche Bank.

Bofinger, P., Debes, S., Gareis, J. and Mayer, E. (2013) 'Monetary Policy Transmission in a Model with Animal Spirits and House Price Booms and Busts', Journal of Economic Dynamics and Control, 37, 2862-2881.

Borio, C. (2014) 'The Financial Cycle and Macroeconomics: What Have We Learnt?', Journal of Banking \& Finance, 45, 182-198.

Charles, S. (2016) 'Is Minsky’s Financial Instability Hypothesis Valid?', Cambridge Journal of Economics, 40, 427-436.

Comin, D. and Gertler, M. (2006) 'Medium-Term Business Cycles', The American Economic Review, 96, 523-551.

De Grauwe, P. and Macchiarelli, C. (2015) 'Animal Spirits and Credit Cycles', Journal of Economic Dynamics and Control, 59, 95-117.

Delli Gatti, D., Gallegati, M., Greenwald, B., Russo, A. and Stiglitz, J. E. (2010) 'The Financial Accelerator in an Evolving Credit Network', Journal of Economic Dynamics and Control, 34, 1627-1650.

Demirgüc-Kunt, A. and Levine, R. (1999) Bank-Based and Market-Based Financial Systems. Cross-Country Comparisons, World Bank Policy Research Working Paper WPS2143.

Drehmann, M., Borio, C. E. and Tsatsaronis, K. (2012) Characterising the Financial Cycle: Don't Lose Sight of the Medium Term!, BIS Working Papers 380.

Eggertsson, G. B. and Krugman, P. (2012) 'Debt, Deleveraging, and the Liquidity Trap: A Fisher-Minsky-Koo Approach', The Quarterly Journal of Economics, 127, 1469-1513. 
Fazzari, S., Ferri, P. and Greenberg, E. (2008) 'Cash Flow, Investment, and Keynes-Minsky Cycles’, Journal of Economic Behavior \& Organization, 65, 555-572.

Fazzari, S. M., Hubbard, R. G. and Petersen, B. C. (1988) 'Financing Constraints and Corporate Investment', Brooking Papers on Economic Activity, 1988, 141-195.

Foley, D. K. (1987) 'Liquidity-Profit Rate Cycles in a Capitalist Economy', Journal of Economic Behavior \& Organization, 8, 363-376.

Hamilton, J. D. (1994) Time Series Analysis, Princeton, New Jersey, Princeton University Press.

Igan, D., Kabundi, A., Nadal De Simone, F., Pinheiro, M. and Tamirisa, N. (2011) 'Housing, Credit, and Real Activity Cycles: Characteristics and Comovement', Journal of Housing Economics, 20, 210-231.

IMF (2017) Global Financial Stability Report October 2017. Is Growth at Risk?, Washington, D.C., U.S, IMF.

Kalecki, M. (1937) 'The Principle of Increasing Risk', Economica, 4, 440-447.

Kim, Y. K. (2013) 'Household Debt, Financialization, and Macroeconomic Performance in the United States, 1951-2009', Journal of Post Keynesian Economics, 35, 675-694.

Kim, Y. K. (2016) 'Macroeconomic Effects of Household Debt: An Empirical Analysis', Review of Keynesian Economics, 4, 127-150.

Kiyotaki, N. and Moore, J. (1997) 'Credit Cycles', Journal of Political Economy, 105, 211248.

Lavoie, M. (2014) Post-Keynesian Economics: New Foundations, Cheltenham; Northampton, MA, Edward Elgar.

Lavoie, M. and Seccareccia, M. (2001) 'Minky's Financial Fragility Hypothesis: A Missing Macroeconomic Link?' In Bellofiore, R. and Ferri, P. (eds) Financial Fragility and Investment in the Capitalist Economy, the Economic Legacy of Hyman Minsky, Cheltenham, Edward Elgar.

Lütkepohl, H. (2005) New Introduction to Multiple Time Series Analysis, Berlin, Heidelberg, Springer.

Ma, Y. and Zhang, J. (2016) 'Financial Cycle, Business Cycle and Monetary Policy: Evidence from Four Major Economies', International Journal of Finance \& Economics, 21, 502527.

Mian, A. R., Sufi, A. and Verner, E. (2015) Household Debt and Business Cycles Worldwide, Working Paper 21581, National Bureau of Economic Research.

Minsky, H. P. (2008) John Maynard Keynes, McGraw-Hill.

Minsky, H. P. (2016) 'The Financial Instability Hypothesis: A Restatement'. In Can 'It' Happen Again? Essays on Instability and Finance, Oxon and New York, Routledge. 
Ndikumana, L. (1999) 'Debt Service, Financing Constraints and Fixed Investment: Evidence from Panel Data', Journal of Post Keynesian Economics, 21, 455-478.

Nikolaidi, M. and Stockhammer, E. (2017) 'Minsky Models. A Structured Survey’, Journal of Economic Surveys, 31, 1304-1331.

Palley, T. I. (1994) 'Debt, Aggregate Demand, and the Business Cycle: An Analysis in the Spirit of Kaldor and Minsky', Journal of Post Keynesian Economics, 16, 371-390.

Pesaran, M. H. (2004) General Diagnostic Tests for Cross Section Dependence in Panels, Cambridge Working Papers in Economics 0435, Faculty of Economics, University of Cambridge.

Pesaran, M. H. (2007) 'A Simple Panel Unit Root Test in the Presence of Cross-Section Dependence', Journal of Applied Econometrics, 22, 265-312.

Ryoo, S. (2010) 'Long Waves and Short Cycles in a Model of Endogenous Financial Fragility', Journal of Economic Behavior \& Organization, 74, 163-186.

Ryoo, S. (2013a) 'Minsky Cycles in Keynesian Models of Growth and Distribution', Review of Keynesian Economics, 1, 37-60.

Ryoo, S. (2016) 'Household Debt and Housing Bubbles: A Minskian Approach to Boom-Bust Cycles', Journal of Evolutionary Economics, 26, 971-1006.

Shibayama, K. (2008) On the Periodicity of Inventories, Working Paper. Department of Economics, University of Kent at Canterbury, Canterbury, Kent.

Sims, C. A., Stock, J. H. and Watson, M. W. (1990) 'Inference in Linear Time Series Models with Some Unit Roots', Econometrica, 58, 113-144.

Strohsal, T., Proaño, C. R. and Wolters, J. (2015) Characterizing the Financial Cycle: Evidence From Frequency Domain Analysis, SFB Discussion Paper 649.

Westerlund, J. (2007) 'Testing for Error Correction in Panel Data', Oxford Bulletin of Economics and Statistics, 69, 709-748. 


\section{Appendix}

\section{A1 Data description}

Table A1: Data definition and sources

\begin{tabular}{|c|c|c|c|c|}
\hline Variable & Abbreviation & Definition & Source(s) & Note \\
\hline Real GDP & $G D P$ & $\begin{array}{l}\text { GDP (B1_GA): output approach, constant } \\
\text { prices, millions. Natural logarithm. }\end{array}$ & OECD stats & \\
\hline Real consumption & CONS & $\begin{array}{l}\text { Final consumption expenditure (P3), } \\
\text { constant prices. Natural logarithm. }\end{array}$ & OECD stats & \\
\hline Real investment & $I N V$ & $\begin{array}{l}\text { Gross fixed capital formation (P51), } \\
\text { constant prices, millions. Natural } \\
\text { logarithm. }\end{array}$ & OECD stats & \\
\hline $\begin{array}{l}\text { Real residential } \\
\text { investment }\end{array}$ & $I N V \_R E S$ & $\begin{array}{l}\text { Gross fixed capital formation: Dwellings } \\
\text { (P51N1111), constant prices, millions. } \\
\text { Natural logarithm. }\end{array}$ & OECD stats & \\
\hline $\begin{array}{l}\text { Non-residential } \\
\text { investment }\end{array}$ & $I N V \_N O N R E S$ & $S I N V-I N V \_R E S$ & & \\
\hline $\begin{array}{l}\text { Short-term real } \\
\text { interest rate }\end{array}$ & INTR & $\begin{array}{l}\text { Average annual interest rate, } \% \text {, based on } \\
\text { three-month money market rates, deflated } \\
\text { by the GDP deflator using the exact } \\
\text { Fisher equation }\end{array}$ & $\begin{array}{l}\text { OECD stats; } \\
\text { AMECO }\end{array}$ & $\begin{array}{l}\text { GDP deflator for Germany from } \\
\text { AMECO; real interest rate for } \\
\text { Finland from AMECO; all other } \\
\text { series from OECD }\end{array}$ \\
\hline $\begin{array}{l}\text { Non-financial } \\
\text { corporation debt to } \\
\text { GDP }\end{array}$ & $N F C D$ & $\begin{array}{l}\text { Debt of non-financial corporations as a } \\
\text { percentage of GDP (market value, } \\
\text { adjusted for breaks) (NAM770A) }\end{array}$ & BIS & \\
\hline $\begin{array}{l}\text { Household debt to } \\
\text { GDP }\end{array}$ & $H H D$ & $\begin{array}{l}\text { Debt of households and NPISH as a } \\
\text { percentage of GDP (market value, } \\
\text { adjusted for breaks) (HAM770A) }\end{array}$ & BIS & \\
\hline $\begin{array}{l}\text { Non-financial } \\
\text { corporation debt to } \\
\text { capital stock }\end{array}$ & $N F C D^{C S T}$ & $\begin{array}{l}\text { Debt of non-financial corporations as a } \\
\text { percentage of total net capital stock }\end{array}$ & $\begin{array}{l}\text { BIS (debt); } \\
\text { AMECO (net } \\
\text { capital stock) }\end{array}$ & Own calculation \\
\hline $\begin{array}{l}\text { Household debt to } \\
\text { capital stock }\end{array}$ & $H H D^{C S T}$ & $\begin{array}{l}\text { Debt of households and NPISH as a } \\
\text { percentage of total net capital stock }\end{array}$ & $\begin{array}{l}\text { BIS (debt); } \\
\text { AMECO (net } \\
\text { capital stock) }\end{array}$ & Own calculation \\
\hline
\end{tabular}




\section{A2 Cross sectional dependence, unit root, and cointegration tests}

Table A2: Time series unit root tests

\begin{tabular}{|l|l|l|l|l|l|l|l|}
\hline & \multicolumn{2}{|c|}{ GDP } & \multicolumn{1}{c|}{ INTR } & \multicolumn{2}{c|}{ NFCD } & \multicolumn{2}{c|}{$H H D$} \\
\hline & Intercept & $\begin{array}{l}\text { Intercept and } \\
\text { trend }\end{array}$ & Intercept & Intercept & $\begin{array}{l}\text { Intercept and } \\
\text { trend }\end{array}$ & Intercept & $\begin{array}{l}\text { Intercept and } \\
\text { trend }\end{array}$ \\
\hline AUS & 0.95 & 0.48 & 0.25 & 0.21 & $0.05 * *$ & 0.99 & 0.65 \\
\hline CAN & 0.14 & 0.15 & 0.17 & 0.83 & 0.24 & 0.97 & 0.59 \\
\hline DEU & 0.21 & 0.80 & 0.62 & 0.31 & 0.26 & 0.25 & 0.95 \\
\hline FIN & 0.36 & 0.31 & 0.58 & 0.64 & 0.14 & 0.94 & 0.13 \\
\hline FRA & 0.11 & 0.78 & 0.31 & 0.99 & 0.27 & 0.89 & 0.60 \\
\hline GBR & 0.84 & 0.23 & 0.21 & 0.59 & 0.25 & 0.97 & $0.01 * * *$ \\
\hline USA & 0.38 & 0.77 & 0.39 & 0.73 & 0.26 & 0.66 & $0.01 * * *$ \\
\hline
\end{tabular}

Note: The table reports the p-value of Augmented Dickey Fuller (ADF) unit root tests. The number of lags was selected based on the Akaike information criterion. The test was run for each series with intercept only, and with intercept and a time trend. AUS: Australia; CAN: Canada; DEU: Germany; FIN: Finland; FRA: France; GBR: Great Britain; USA: United States. *, **, *** denote statistical significance at the 1, 5, and 10\%-level, respectively.

Table A3: Cross-sectional dependence test

\begin{tabular}{|l|l|l|}
\hline & CD-test statistic & p-value \\
\hline$G D P$ & 27.11 & $0.00 * * *$ \\
\hline$I N T R$ & 18.31 & $0.00 * * *$ \\
\hline$N F C D$ & 20.71 & $0.00 * * *$ \\
\hline$H H D$ & 18.98 & $0.00 * * *$ \\
\hline
\end{tabular}

Note: The table reports test statistics and p-values of the Pesaran (2004) cross sectional dependence test. The test was run for the full panel. *,**,*** denote statistical significance at the 1,5 , and $10 \%$-level, respectively.

Table A4: Cross-sectionally augmented panel unit root test

\begin{tabular}{|l|l|l|l|l|l|l|l|}
\hline \multicolumn{2}{|c|}{} & \multicolumn{2}{c|}{ INTR } & \multicolumn{2}{c|}{ NFCD } & \multicolumn{2}{c|}{$H H D$} \\
\hline Intercept & $\begin{array}{l}\text { Intercept and } \\
\text { trend }\end{array}$ & Intercept & $\begin{array}{l}\text { Intercept and } \\
\text { trend }\end{array}$ & Intercept & $\begin{array}{l}\text { Intercept and } \\
\text { trend }\end{array}$ & Intercept & $\begin{array}{l}\text { Intercept and } \\
\text { trend }\end{array}$ \\
\hline 0.988 & 0.910 & $0.013^{* *}$ & 0.366 & 0.894 & 0.999 & 0.635 & 0.918 \\
\hline
\end{tabular}

Note: The table reports p-values of the Pesaran (2007) cross-sectionally augmented panel unit root test (CADF). The test was run for the full panel with two lags. *,**,*** denote statistical significance at the 1,5 , and $10 \%$ level, respectively. 
Table A5: Panel cointegration test

\begin{tabular}{|l|l|l|l|l|}
\hline & Gt test statistic & $\begin{array}{l}\text { Ga test } \\
\text { statistic }\end{array}$ & Pt test statistic & $\begin{array}{l}\text { Pa test } \\
\text { statistic }\end{array}$ \\
\hline$G D P-I N T R$ & 2.679 & 0.140 & 6.922 & 0.116 \\
\hline$I N T R-G D P$ & $-2.082 * * *$ & -3.524 & $-5.314 * * *$ & $-3.768^{* *}$ \\
\hline$G D P-N F C D$ & 2.362 & 0.594 & 5.487 & 0.366 \\
\hline$N F C D-G D P$ & -0.700 & -1.735 & -2.803 & -1.790 \\
\hline$G D P-H H D$ & 2.820 & 0.329 & 7.389 & 0.310 \\
\hline$H H D-G D P$ & -0.070 & -0.291 & -0.843 & -0.384 \\
\hline
\end{tabular}

Note: The table reports test statistics of the Westerlund (2007) panel cointegration test. The test was run for the full panel with the number of lags selected by the Akaike information criterion. A Bartlett kernel window width was set according to $4(T / 100)^{2 / 9} \approx 3$. The Gt and Ga test statistics are based on a mean-group estimator, and the Pt and Pa test statistics on a panel estimator. The suffixes ' $t$ ' and ' $a$ ' indicate that the test-statistic was constructed with the t-statistics of the individual panels (' $t$ ') or with a weighted average of the point estimates of the individual panels ('a'). *, **, *** denote statistical significance at the 1,5 , and $10 \%$-level, respectively, which are based on bootstrapped critical values that allow for the presence of cross-sectional dependence. 


\section{A3 Serial correlation tests}

Table A6: Serial correlation LM-tests for VARs with GDP and INTR

\begin{tabular}{|c|c|c|c|}
\hline Country & Lag & $\begin{array}{l}\text { LM- } \\
\text { Statistic }\end{array}$ & P-value \\
\hline \multirow{4}{*}{ AUS } & 1 & 6.63 & 0.16 \\
\hline & 2 & 1.87 & 0.76 \\
\hline & 3 & 5.10 & 0.28 \\
\hline & 4 & 4.93 & 0.29 \\
\hline \multirow{4}{*}{ CAN } & 1 & 3.35 & 0.50 \\
\hline & 2 & 6.95 & 0.14 \\
\hline & 3 & 1.46 & 0.83 \\
\hline & 4 & 2.47 & 0.65 \\
\hline \multirow{4}{*}{ DEU } & 1 & 2.19 & 0.70 \\
\hline & 2 & 4.32 & 0.36 \\
\hline & 3 & 1.14 & 0.89 \\
\hline & 4 & 0.78 & 0.94 \\
\hline \multirow{4}{*}{ FIN } & 1 & 2.33 & 0.67 \\
\hline & 2 & 5.49 & 0.24 \\
\hline & 3 & 2.95 & 0.57 \\
\hline & 4 & 1.18 & 0.88 \\
\hline \multirow{4}{*}{ FRA } & 1 & 0.83 & 0.93 \\
\hline & 2 & 3.87 & 0.42 \\
\hline & 3 & 8.28 & $0.08^{*}$ \\
\hline & 4 & 0.58 & 0.97 \\
\hline \multirow{4}{*}{ GBR } & 1 & 2.49 & 0.65 \\
\hline & 2 & 1.60 & 0.81 \\
\hline & 3 & 0.11 & 1.00 \\
\hline & 4 & 5.83 & 0.21 \\
\hline \multirow{4}{*}{ USA } & 1 & 3.39 & 0.49 \\
\hline & 2 & 1.10 & 0.89 \\
\hline & 3 & 5.64 & 0.23 \\
\hline & 4 & 7.67 & 0.10 \\
\hline
\end{tabular}

Notes: AUS: Australia; CAN: Canada; DEU: Germany; FIN: Finland; FRA: France; GBR: Great Britain; USA: United States . Null hypothesis of LM-test: No serial correlation. *,**,*** denote statistical significance at the 1,5 , and $10 \%$-level, respectively. 
Table A7: Serial correlation LM-tests for VARs with GDP and NFCD

\begin{tabular}{|c|c|c|c|}
\hline Country & Lag & $\begin{array}{l}\text { LM- } \\
\text { statistic }\end{array}$ & P-value \\
\hline \multirow[t]{4}{*}{ AUS } & 1 & 6.08 & 0.19 \\
\hline & 2 & 4.34 & 0.36 \\
\hline & 3 & 2.20 & 0.70 \\
\hline & 4 & 7.31 & 0.12 \\
\hline \multirow[t]{4}{*}{ CAN } & 1 & 2.40 & 0.66 \\
\hline & 2 & 2.15 & 0.71 \\
\hline & 3 & 0.19 & 1.00 \\
\hline & 4 & 0.90 & 0.92 \\
\hline \multirow[t]{4}{*}{ DEU } & 1 & 2.66 & 0.62 \\
\hline & 2 & 1.76 & 0.78 \\
\hline & 3 & 1.89 & 0.76 \\
\hline & 4 & 0.78 & 0.94 \\
\hline \multirow[t]{4}{*}{ FIN } & 1 & 7.46 & 0.11 \\
\hline & 2 & 6.20 & 0.18 \\
\hline & 3 & 1.73 & 0.78 \\
\hline & 4 & 1.74 & 0.78 \\
\hline \multirow[t]{4}{*}{ FRA } & 1 & 7.15 & 0.13 \\
\hline & 2 & 2.05 & 0.73 \\
\hline & 3 & 2.30 & 0.68 \\
\hline & 4 & 0.30 & 0.99 \\
\hline \multirow[t]{4}{*}{ GBR } & 1 & 2.55 & 0.64 \\
\hline & 2 & 5.93 & 0.20 \\
\hline & 3 & 5.01 & 0.29 \\
\hline & 4 & 1.34 & 0.85 \\
\hline \multirow[t]{4}{*}{ USA } & 1 & 3.80 & 0.43 \\
\hline & 2 & 3.59 & 0.47 \\
\hline & 3 & 1.31 & 0.86 \\
\hline & 4 & 3.78 & 0.44 \\
\hline
\end{tabular}

Notes: AUS: Australia; CAN: Canada; DEU: Germany;

FIN: Finland; FRA: France; GBR: Great Britain;

USA: United States. Null hypothesis of LM-test: No serial correlation.

$*$, **, *** denote statistical significance at the 1,5 , and $10 \%$-level, respectively. 
Table A8: Serial correlation LM-tests for VARs with GDP and $H H D$

\begin{tabular}{|c|c|c|c|}
\hline Country & Lag & $\begin{array}{l}\text { LM- } \\
\text { Statistic }\end{array}$ & P-value \\
\hline \multirow[t]{4}{*}{ AUS } & 1 & 2.35 & 0.67 \\
\hline & 2 & 3.48 & 0.48 \\
\hline & 3 & 4.34 & 0.36 \\
\hline & 4 & 2.47 & 0.65 \\
\hline \multirow[t]{4}{*}{ CAN } & 1 & 4.61 & 0.33 \\
\hline & 2 & 0.37 & 0.98 \\
\hline & 3 & 1.39 & 0.85 \\
\hline & 4 & 1.77 & 0.78 \\
\hline \multirow[t]{4}{*}{ DEU } & 1 & 7.38 & 0.12 \\
\hline & 2 & 5.11 & 0.28 \\
\hline & 3 & 3.24 & 0.52 \\
\hline & 4 & 2.34 & 0.67 \\
\hline \multirow[t]{4}{*}{ FIN } & 1 & 3.32 & 0.51 \\
\hline & 2 & 3.15 & 0.53 \\
\hline & 3 & 3.71 & 0.45 \\
\hline & 4 & 4.36 & 0.36 \\
\hline \multirow[t]{4}{*}{ FRA } & 1 & 5.26 & 0.26 \\
\hline & 2 & 2.44 & 0.66 \\
\hline & 3 & 2.15 & 0.71 \\
\hline & 4 & 3.55 & 0.47 \\
\hline \multirow[t]{4}{*}{ GBR } & 1 & 5.31 & 0.26 \\
\hline & 2 & 3.65 & 0.46 \\
\hline & 3 & 3.13 & 0.54 \\
\hline & 4 & 4.54 & 0.34 \\
\hline \multirow[t]{4}{*}{ USA } & 1 & 2.11 & 0.71 \\
\hline & 2 & 3.77 & 0.44 \\
\hline & 3 & 7.37 & 0.12 \\
\hline & 4 & 7.23 & 0.12 \\
\hline
\end{tabular}

Notes: AUS: Australia; CAN: Canada; DEU: Germany;

FIN: Finland; FRA: France; GBR: Great Britain; USA: United States. Null hypothesis of LM-test: No serial correlation. $* * *, * * *$ denote statistical significance at the 1,5 , and $10 \%$-level, respectively. 
A4 Robustness checks

Table A9: VAR models with GDP and NFCD ${ }^{C P S T}$

\begin{tabular}{|c|c|c|c|c|c|c|c|c|}
\hline Country & DV & EPV & $\begin{array}{l}\text { Coeff } \\
\text { LDV }\end{array}$ & $\begin{array}{l}\text { Coeff } \\
\text { EPV }\end{array}$ & $\begin{array}{l}\text { Lag } \\
\text { order }\end{array}$ & $\begin{array}{l}\text { Necessary condition } \\
\text { satisfied? }\end{array}$ & Period & $\begin{array}{l}\text { Cycle } \\
\text { length }\end{array}$ \\
\hline \multirow[t]{2}{*}{ AUS } & GDP & $N F C D^{C P S T}$ & $\begin{array}{c}1.099 \\
(0.166)^{* * *}\end{array}$ & $\begin{array}{c}0.031 \\
(0.157)^{* *}\end{array}$ & \multirow[t]{2}{*}{2} & \multirow[t]{2}{*}{ No } & \multirow[t]{2}{*}{$\begin{array}{l}1979- \\
2014\end{array}$} & \multirow[t]{2}{*}{15.97} \\
\hline & $N F C D^{C P S T}$ & GDP & $\begin{array}{c}1.385 \\
(0.124)^{* * *}\end{array}$ & $\begin{array}{c}0.308 \\
(0.132)\end{array}$ & & & & \\
\hline \multirow[t]{2}{*}{ CAN } & $G D P$ & $N F C D^{C P S T}$ & $\begin{array}{c}1.274 \\
(0.142)^{* * *}\end{array}$ & $\begin{array}{c}-0.412 \\
(0.195)^{* *}\end{array}$ & \multirow[t]{2}{*}{2} & \multirow[t]{2}{*}{ Yes } & \multirow[t]{2}{*}{$\begin{array}{l}1973- \\
2015\end{array}$} & \multirow[t]{2}{*}{7.42} \\
\hline & $N F C D^{C P S T}$ & $G D P$ & $\begin{array}{c}1.063 \\
(0.152)^{* * *}\end{array}$ & $\begin{array}{c}0.207 \\
(0.111)^{*}\end{array}$ & & & & \\
\hline \multirow[t]{2}{*}{$\overline{D E U}$} & $G D P$ & $N F C D^{C P S T}$ & $\begin{array}{c}1.053 \\
(0.153)^{* * *}\end{array}$ & $\begin{array}{l}-0.386 \\
(0.632)\end{array}$ & \multirow[t]{2}{*}{2} & \multirow[t]{2}{*}{ Yes } & \multirow[t]{2}{*}{$\begin{array}{l}1973- \\
2015\end{array}$} & \multirow[t]{2}{*}{10.33} \\
\hline & $N F C D^{C P S T}$ & $G D P$ & $\begin{array}{c}0.962 \\
(0.141)^{* * *}\end{array}$ & $\begin{array}{c}0.021 \\
(0.034)\end{array}$ & & & & \\
\hline \multirow[t]{2}{*}{ FIN } & $G D P$ & $N F C D^{C P S T}$ & $\begin{array}{c}1.529 \\
(0.131)^{* * *}\end{array}$ & $\begin{array}{c}-0.888 \\
(0.210)^{* * *}\end{array}$ & \multirow[t]{2}{*}{3} & \multirow[t]{2}{*}{ No } & \multirow[t]{2}{*}{$\begin{array}{l}1974- \\
2015\end{array}$} & \multirow[t]{2}{*}{$6.54 ; 2.85$} \\
\hline & $N F C D^{C P S T}$ & $G D P$ & $\begin{array}{c}0.418 \\
(0.140)^{* * *}\end{array}$ & $\begin{array}{c}-0.194 \\
(0.087)^{* *}\end{array}$ & & & & \\
\hline \multirow[t]{2}{*}{ FRA } & GDP & $N F C D^{C P S T}$ & $\begin{array}{c}1.30037 \\
(0.174)^{* * *}\end{array}$ & $\begin{array}{l}-0.380 \\
(0.263)\end{array}$ & \multirow[t]{2}{*}{2} & \multirow[t]{2}{*}{ Yes } & \multirow[t]{2}{*}{$\begin{array}{l}1979- \\
2015\end{array}$} & \multirow[t]{2}{*}{23} \\
\hline & $N F C D^{C P S T}$ & GDP & $\begin{array}{c}0.913 \\
(0.168)^{* * *}\end{array}$ & $\begin{array}{l}0.2676069 \\
(0.111)^{* *}\end{array}$ & & & & \\
\hline \multirow[t]{2}{*}{ GBR } & GDP & $N F C D^{C P S T}$ & $\begin{array}{c}1.449 \\
(0.154)^{* * *}\end{array}$ & $\begin{array}{c}-0.243 \\
(0.202)^{*}\end{array}$ & \multirow[t]{2}{*}{2} & \multirow[t]{2}{*}{ Yes } & \multirow[t]{2}{*}{$\begin{array}{l}1978- \\
2015\end{array}$} & \multirow[t]{2}{*}{17.28} \\
\hline & $N F C D^{C P S T}$ & GDP & $\begin{array}{c}1.162 \\
(0.152)^{* * *}\end{array}$ & $\begin{array}{c}0.226 \\
(0.116)\end{array}$ & & & & \\
\hline \multirow[t]{2}{*}{ USA } & $G D P$ & $N F C D^{C P S T}$ & $\begin{array}{c}1.342 \\
(0.179)^{* * *}\end{array}$ & $\begin{array}{c}-0.560 \\
(0.416) *\end{array}$ & \multirow[t]{2}{*}{2} & \multirow[t]{2}{*}{ Yes } & \multirow[t]{2}{*}{$\begin{array}{l}1973- \\
2015\end{array}$} & \multirow[t]{2}{*}{10.36} \\
\hline & $N F C D^{C P S T}$ & $G D P$ & $\begin{array}{c}1.295 \\
(0.130)^{* * *}\end{array}$ & $\begin{array}{c}0.100 \\
(0.056)\end{array}$ & & & & \\
\hline $\begin{array}{l}\text { Avr. cycle } \\
\text { length }\end{array}$ & & & & & & & & 12.99 \\
\hline
\end{tabular}

Notes: AUS: Australia; CAN: Canada; DEU: Germany; FIN: Finland; FRA: France; GBR: Great Britain; USA: United States. DVL: Dependent variable. LDV: First lagged dependent variable. EPV: First lag of explanatory variable. Standard errors in parentheses. $*, * *, * * *$ denote statistical significance at the 1,5 , and $10 \%$-level, respectively. Necessary condition: $\alpha_{2} \beta_{1}<0$. All specifications were estimated with a constant (not reported). For the average cycle length, we used the longer cycle period, when the system has more than one complex eigenvalue. 
Table A10: VAR models with $G D P$ and $H H D^{C P S T}$

\begin{tabular}{|c|c|c|c|c|c|c|c|c|}
\hline Country & DV & EPV & Coeff LDV & Coeff EPV & $\begin{array}{l}\text { Lag } \\
\text { order }\end{array}$ & $\begin{array}{l}\text { Necessary } \\
\text { condition } \\
\text { satisfied? }\end{array}$ & Period & Cycle length \\
\hline \multirow[t]{2}{*}{ AUS } & $G D P$ & $H H D^{C P S T}$ & $\begin{array}{c}1.091 \\
(0.174)^{* * *}\end{array}$ & $\begin{array}{c}0.050 \\
(0.232)\end{array}$ & \multirow[t]{2}{*}{2} & \multirow[t]{2}{*}{ No } & \multirow[t]{2}{*}{ 1979-2014 } & \multirow[t]{2}{*}{28.69} \\
\hline & $H H D^{C P S T}$ & $G D P$ & $\begin{array}{c}1.463 \\
(0.136)^{* * *}\end{array}$ & $\begin{array}{l}0.107 \\
(0.102)\end{array}$ & & & & \\
\hline \multirow[t]{2}{*}{ CAN } & $G D P$ & $H H D^{C P S T}$ & $\begin{array}{c}1.152 \\
(0.143)^{* * *}\end{array}$ & $\begin{array}{c}0.719 \\
(0.319)^{* *}\end{array}$ & \multirow[t]{2}{*}{2} & \multirow[t]{2}{*}{ No } & \multirow[t]{2}{*}{ 1973-2015 } & \multirow[t]{2}{*}{46.99} \\
\hline & $H H D^{C P S T}$ & $G D P$ & $\begin{array}{c}0.028 \\
(0.057)^{* * *}\end{array}$ & $\begin{array}{r}1.418 \\
(0.127)\end{array}$ & & & & \\
\hline \multirow[t]{2}{*}{$\mathrm{DEU}$} & $G D P$ & $H H D^{C P S T}$ & $\begin{array}{c}1.076 \\
(0.149)^{* * *}\end{array}$ & $\begin{array}{l}0.667 \\
(0.537)\end{array}$ & \multirow[t]{2}{*}{2} & \multirow[t]{2}{*}{ Yes } & \multirow[t]{2}{*}{$1973-2015$} & \multirow[t]{2}{*}{24.44} \\
\hline & $H H D^{C P S T}$ & $G D P$ & $\begin{array}{c}1.419 \\
(0.132)\end{array}$ & $\begin{array}{c}-0.074 \\
(0.037)^{* *}\end{array}$ & & & & \\
\hline \multirow[t]{2}{*}{ FIN } & $G D P$ & $H H D^{C P S T}$ & $\begin{array}{c}1.294 \\
(0.140)^{* * *}\end{array}$ & $\begin{array}{l}0.122 \\
(0.472)\end{array}$ & \multirow[t]{2}{*}{2} & \multirow[t]{2}{*}{ No } & \multirow[t]{2}{*}{ 1973-2015 } & \multirow[t]{2}{*}{95.20} \\
\hline & $H H D^{C P S T}$ & $G D P$ & $\begin{array}{c}1.083 \\
(0.141)^{* * *}\end{array}$ & $\begin{array}{c}0.049 \\
(0.042)\end{array}$ & & & & \\
\hline \multirow[t]{2}{*}{ FRA } & $G D P$ & $H H D^{C P S T}$ & $\begin{array}{c}1.254 \\
(0.156)^{* * *}\end{array}$ & $\begin{array}{c}1.228 \\
(0.571)^{* *}\end{array}$ & \multirow[t]{2}{*}{4} & \multirow[t]{2}{*}{ No } & \multirow[t]{2}{*}{ 1981-2015 } & \multirow[t]{2}{*}{$\begin{array}{c}24.28 ; 3.04 \\
6.02\end{array}$} \\
\hline & $H H D^{C P S T}$ & $G D P$ & $\begin{array}{c}1.235 \\
(0.147)^{* * *}\end{array}$ & $\begin{array}{l}0.027 \\
(0.040)\end{array}$ & & & & \\
\hline \multirow[t]{2}{*}{ GBR } & $G D P$ & $H H D^{C P S T}$ & $\begin{array}{c}1.125 \\
(0.137)^{* * *}\end{array}$ & $\begin{array}{c}1.461 \\
(0.510) * * *\end{array}$ & \multirow[t]{2}{*}{3} & \multirow[t]{2}{*}{ Yes } & \multirow[t]{2}{*}{$1974-2015$} & \multirow[t]{2}{*}{$\begin{array}{c}19.66 \\
4.92\end{array}$} \\
\hline & $H H D^{C P S T}$ & $G D P$ & $\begin{array}{c}1.537 \\
(0.160)^{* * *}\end{array}$ & $\begin{array}{l}-0.015 \\
(0.043)\end{array}$ & & & & \\
\hline \multirow[t]{2}{*}{ USA } & $G D P$ & $H H D^{C P S T}$ & $\begin{array}{c}0.926 \\
(0.155)^{* * *}\end{array}$ & $\begin{array}{c}1.550 \\
(0.428) * * *\end{array}$ & \multirow[t]{2}{*}{4} & \multirow[t]{2}{*}{ Yes } & \multirow[t]{2}{*}{$1975-2014$} & \multirow{2}{*}{$\begin{array}{l}18.53 ; \\
6.02 \\
2.92\end{array}$} \\
\hline & $H H D^{C P S T}$ & $G D P$ & $\begin{array}{c}1.712 \\
(0.144)^{* * *}\end{array}$ & $\begin{array}{l}-0.049 \\
(0.052)\end{array}$ & & & & \\
\hline $\begin{array}{l}\text { Avr. cycle } \\
\text { length }\end{array}$ & & & & & & & & $\begin{array}{l}36.82 ; \\
23.12 \quad \text { (w/o } \\
\text { FIN) }\end{array}$ \\
\hline
\end{tabular}

Notes: AUS: Australia; CAN: Canada; DEU: Germany; FIN: Finland; FRA: France; GBR: Great Britain; USA: United States. DVL: Dependent variable. LDV: First lagged dependent variable. EPV: First lag of explanatory variable. Standard errors in parentheses. $*, * *, * * *$ denote statistical significance at the 1,5 , and $10 \%$-level, respectively. Necessary condition: $\alpha_{2} \beta_{1}<0$. All specifications were estimated with a constant (not reported). For the average cycle length, we used the longer cycle period, when the system has more than one complex eigenvalue. 
Table A11: VAR models with GDP and $N F C D^{D L O G}$

\begin{tabular}{|c|c|c|c|c|c|c|c|c|}
\hline Country & DV & EPV & $\begin{array}{l}\text { Coeff } \\
\text { LDV }\end{array}$ & $\begin{array}{l}\text { Coeff } \\
\text { EPV }\end{array}$ & $\begin{array}{l}\text { Lag } \\
\text { order }\end{array}$ & $\begin{array}{l}\text { Necessary } \\
\text { condition } \\
\text { satisfied? }\end{array}$ & Period & Cycle length \\
\hline \multirow[t]{2}{*}{ AUS } & $G D P$ & $N F C D^{D L O G}$ & $\begin{array}{c}1.110 \\
(0.166)^{* * *}\end{array}$ & $\begin{array}{c}0.033 \\
(0.050)\end{array}$ & \multirow[t]{2}{*}{2} & \multirow[t]{2}{*}{ No } & \multirow[t]{2}{*}{$\begin{array}{l}1980- \\
2014\end{array}$} & \multirow[t]{2}{*}{10.44} \\
\hline & $N F C D^{D L O G}$ & $G D P$ & $\begin{array}{c}0.587 \\
(0.155)^{* * *}\end{array}$ & $\begin{array}{c}1.283 \\
(0.514)^{* *}\end{array}$ & & & & \\
\hline \multirow[t]{2}{*}{ CAN } & $G D P$ & $N F C D^{D L O G}$ & $\begin{array}{c}1.230 \\
(0.147)^{* * *}\end{array}$ & $\begin{array}{c}-0.149 \\
(0.067)^{* *}\end{array}$ & \multirow[t]{2}{*}{2} & \multirow[t]{2}{*}{ Yes } & \multirow[t]{2}{*}{$\begin{array}{l}1973- \\
2015\end{array}$} & \multirow[t]{2}{*}{6.24} \\
\hline & $N F C D^{D L O G}$ & $G D P$ & $\begin{array}{c}0.228 \\
(0.158)\end{array}$ & $\begin{array}{c}0.664 \\
(0.348)^{* *}\end{array}$ & & & & \\
\hline \multirow[t]{2}{*}{ DEU } & $G D P$ & $N F C D^{D L O G}$ & $\begin{array}{c}1.003 \\
(0.155)^{* * *}\end{array}$ & $\begin{array}{c}0.075 \\
(0.102)\end{array}$ & \multirow[t]{2}{*}{3} & \multirow[t]{2}{*}{$\mathrm{No}$} & \multirow[t]{2}{*}{$\begin{array}{l}\text { 1974- } \\
2015\end{array}$} & \multirow[t]{2}{*}{$\begin{array}{l}8.10 \\
3.37\end{array}$} \\
\hline & $N F C D^{D L O G}$ & $G D P$ & $\begin{array}{c}0.055 \\
(0.158)\end{array}$ & $\begin{array}{c}0.423 \\
(0.241)^{*}\end{array}$ & & & & \\
\hline \multirow[t]{2}{*}{ FIN } & $G D P$ & $N F C D^{D L O G}$ & $\begin{array}{c}1.573 \\
(0.154)^{* * *}\end{array}$ & $\begin{array}{c}-0.159 \\
(0.053)^{*}\end{array}$ & \multirow[t]{2}{*}{4} & \multirow[t]{2}{*}{ Yes } & \multirow[t]{2}{*}{$\begin{array}{l}1975- \\
2015\end{array}$} & $\begin{array}{l}\text { 10.03; } \\
4.33\end{array}$ \\
\hline & $N F C D^{D L O G}$ & $G D P$ & $\begin{array}{c}-0.223 \\
(0.124)^{* * *}\end{array}$ & $\begin{array}{c}0.030 \\
(0.361)\end{array}$ & & & & 3.00 \\
\hline \multirow[t]{2}{*}{ FRA } & $G D P$ & $N F C D^{D L O G}$ & $\begin{array}{c}1.344 \\
(0.198)^{* * *}\end{array}$ & $\begin{array}{l}-0.030 \\
(0.095)\end{array}$ & \multirow[t]{2}{*}{2} & \multirow[t]{2}{*}{ Yes } & \multirow[t]{2}{*}{$\begin{array}{l}1980- \\
2015\end{array}$} & \multirow[t]{2}{*}{6.43} \\
\hline & $N F C D^{D L O G}$ & $G D P$ & $\begin{array}{c}0.163 \\
(0.187)^{* * *}\end{array}$ & $\begin{array}{c}1.057 \\
(0.390)^{* * *}\end{array}$ & & & & \\
\hline \multirow[t]{2}{*}{ GBR } & $G D P$ & $N F C D^{D L O G}$ & $\begin{array}{c}1.426 \\
(0.149)^{* * *}\end{array}$ & $\begin{array}{l}-0.011 \\
(0.050)\end{array}$ & \multirow[t]{2}{*}{2} & \multirow[t]{2}{*}{ Yes } & \multirow[t]{2}{*}{$\begin{array}{l}1979- \\
2015\end{array}$} & \multirow[t]{2}{*}{$\begin{array}{l}\text { No complex } \\
\text { eigenvalues }\end{array}$} \\
\hline & $N F C D^{D L O G}$ & $G D P$ & $\begin{array}{c}0.153 \\
(0.146)\end{array}$ & $\begin{array}{c}1.141 \\
(0.438)^{* * *}\end{array}$ & & & & \\
\hline \multirow[t]{2}{*}{ USA } & $G D P$ & $N F C D^{D L O G}$ & $\begin{array}{c}1.287 \\
(0.226)^{* * *}\end{array}$ & $\begin{array}{l}-0.033 \\
(0.141)\end{array}$ & \multirow[t]{2}{*}{2} & \multirow[t]{2}{*}{ Yes } & \multirow[t]{2}{*}{$\begin{array}{l}\text { 1973- } \\
2014\end{array}$} & \multirow[t]{2}{*}{7.01} \\
\hline & $N F C D^{D L O G}$ & $G D P$ & $\begin{array}{c}0.710 \\
(0.216)^{* * *}\end{array}$ & $\begin{array}{c}0.235 \\
(0.346)\end{array}$ & & & & \\
\hline $\begin{array}{l}\text { Avr. cycle } \\
\text { length }\end{array}$ & & & & & & & & 8.04 \\
\hline
\end{tabular}

Notes: AUS: Australia; CAN: Canada; DEU: Germany; FIN: Finland; FRA: France; GBR: Great Britain; USA: United States. DVL: Dependent variable. LDV: First lagged dependent variable. EPV: First lag of explanatory variable. Standard errors in parentheses. $*, * *, * * *$ denote statistical significance at the 1,5, and 10\%-level, respectively. Necessary condition: $\alpha_{2} \beta_{1}<0$. All specifications were estimated with a constant (not reported). For the average cycle length, we used the longer cycle period, when the system has more than one complex eigenvalue. 
Table A12: VAR models with $G D P$ and $H H D^{D L O G}$

\begin{tabular}{|c|c|c|c|c|c|c|c|c|}
\hline Country & DV & EPV & Coeff LDV & Coeff EPV & $\begin{array}{l}\text { Lag } \\
\text { order }\end{array}$ & $\begin{array}{l}\text { Necessary } \\
\text { condition } \\
\text { satisfied? }\end{array}$ & Period & $\begin{array}{l}\text { Cycle } \\
\text { length }\end{array}$ \\
\hline \multirow[t]{2}{*}{ AUS } & $G D P$ & $H H D^{D L O G}$ & $\begin{array}{c}1.223 \\
(0.199)^{* * *}\end{array}$ & $\begin{array}{l}-0.091 \\
(0.095)\end{array}$ & \multirow[t]{2}{*}{2} & \multirow[t]{2}{*}{ Yes } & \multirow[t]{2}{*}{$\begin{array}{l}1980- \\
2014\end{array}$} & \multirow[t]{2}{*}{4.01} \\
\hline & $H H D^{D L O G}$ & $G D P$ & $\begin{array}{c}0.311 \\
(0.189)^{*}\end{array}$ & $\begin{array}{c}0.861 \\
(0.394)^{* *}\end{array}$ & & & & \\
\hline \multirow[t]{2}{*}{ CAN } & $G D P$ & $H H D^{D L O G}$ & $\begin{array}{c}1.184 \\
(0.133)^{* * *}\end{array}$ & $\begin{array}{c}0.326 \\
(0.082)^{* * *}\end{array}$ & \multirow[t]{2}{*}{2} & \multirow[t]{2}{*}{ No } & \multirow[t]{2}{*}{$\begin{array}{l}1973- \\
2015\end{array}$} & \multirow[t]{2}{*}{8.66} \\
\hline & $H H D^{D L O G}$ & $G D P$ & $\begin{array}{c}0.860 \\
(0.145)^{* * *}\end{array}$ & $\begin{array}{l}-0.047 \\
(0.237)\end{array}$ & & & & \\
\hline \multirow[t]{2}{*}{ DEU } & $G D P$ & $H H D^{D L O G}$ & $\begin{array}{c}1.041 \\
(0.143)^{* * *}\end{array}$ & $\begin{array}{c}0.325 \\
(0.130)^{*}\end{array}$ & \multirow[t]{2}{*}{2} & \multirow[t]{2}{*}{ Yes } & \multirow[t]{2}{*}{$\begin{array}{l}1973- \\
2015\end{array}$} & \multirow[t]{2}{*}{4.65} \\
\hline & $H H D^{D L O G}$ & $G D P$ & $0.761(0.141)$ & $\begin{array}{l}-0.350 \\
(0.155)\end{array}$ & & & & \\
\hline \multirow[t]{2}{*}{ FIN } & $G D P$ & $H H D^{D L O G}$ & $\begin{array}{c}0.989 \\
(0.161)^{* * *}\end{array}$ & $\begin{array}{c}0.346 \\
(0.075)^{* * *}\end{array}$ & \multirow[t]{2}{*}{5} & \multirow[t]{2}{*}{ Yes } & \multirow[t]{2}{*}{$\begin{array}{l}1976- \\
2015\end{array}$} & $\begin{array}{l}19.25 \\
5.28\end{array}$ \\
\hline & $H H D^{D L O G}$ & $G D P$ & $\begin{array}{c}0.686 \\
(0.130)^{* * *}\end{array}$ & $\begin{array}{l}-0.157 \\
(0.277)\end{array}$ & & & & $\begin{array}{l}3.32 \\
2.85\end{array}$ \\
\hline \multirow[t]{2}{*}{ FRA } & $G D P$ & $H H D^{D L O G}$ & $\begin{array}{c}1.260 \\
(0.155)^{* * *}\end{array}$ & $\begin{array}{c}0.106 \\
(0.062)^{*}\end{array}$ & \multirow[t]{2}{*}{3} & \multirow[t]{2}{*}{ No } & \multirow[t]{2}{*}{$\begin{array}{l}1981- \\
2015\end{array}$} & \multirow[t]{2}{*}{$\begin{array}{c}21.26 \\
3.20\end{array}$} \\
\hline & $H H D^{D L O G}$ & $G D P$ & $\begin{array}{c}0.321 \\
(0.155)^{* *}\end{array}$ & $\begin{array}{c}0.559 \\
(0.388)^{* * *}\end{array}$ & & & & \\
\hline \multirow[t]{2}{*}{ GBR } & $G D P$ & $H H D^{D L O G}$ & $\begin{array}{c}1.118 \\
(0.154)^{* * *}\end{array}$ & $\begin{array}{c}0.279 \\
(0.069)^{* * *}\end{array}$ & \multirow[t]{2}{*}{2} & \multirow[t]{2}{*}{ Yes } & \multirow[t]{2}{*}{$\begin{array}{l}1973- \\
2015\end{array}$} & \multirow[t]{2}{*}{5.14} \\
\hline & $H H D^{D L O G}$ & $G D P$ & $\begin{array}{c}0.739 \\
(0.160)^{* * *}\end{array}$ & $\begin{array}{l}-0.255 \\
(0.357)\end{array}$ & & & & \\
\hline \multirow[t]{2}{*}{ USA } & $G D P$ & $H H D^{D L O G}$ & $\begin{array}{c}0.785 \\
(0.179)^{* * *}\end{array}$ & $\begin{array}{c}0.465 \\
(0.120)^{* * *}\end{array}$ & \multirow[t]{2}{*}{5} & \multirow[t]{2}{*}{ Yes } & \multirow[t]{2}{*}{$\begin{array}{l}1976- \\
2014\end{array}$} & $\begin{array}{l}14.58 \\
7.09\end{array}$ \\
\hline & $H H D^{D L O G}$ & $G D P$ & $\begin{array}{c}1.174 \\
(0.171)^{* * *}\end{array}$ & $\begin{array}{l}-0.211 \\
(0.254)\end{array}$ & & & & 4.64 \\
\hline $\begin{array}{l}\text { Avr. cycle } \\
\text { length }\end{array}$ & & & & & & & & 11.08 \\
\hline
\end{tabular}

Notes: AUS: Australia; CAN: Canada; DEU: Germany; FIN: Finland; FRA: France; GBR: Great Britain; USA: United States. DVL: Dependent variable. LDV: First lagged dependent variable. EPV: First lag of explanatory variable. Standard errors in parentheses. $*, * *, * * *$ denote statistical significance at the 1,5 , and $10 \%$-level, respectively. Necessary condition: $\alpha_{2} \beta_{1}<0$. All specifications were estimated with a constant (not reported). For the average cycle length, we used the longer cycle period, when the system has more than one complex eigenvalue. 


\section{A5 Further estimations}

Table A13: VAR models with INTR and INV

\begin{tabular}{|c|c|c|c|c|c|c|c|c|}
\hline Country & DV & EPV & $\begin{array}{l}\text { Coeff } \\
\text { LDV }\end{array}$ & $\begin{array}{l}\text { Coeff } \\
\text { EPV }\end{array}$ & $\begin{array}{l}\text { Lag } \\
\text { order }\end{array}$ & $\begin{array}{l}\text { Necessary } \\
\text { condition } \\
\text { satisfied? }\end{array}$ & Period & Cycle length \\
\hline \multirow[t]{2}{*}{ AUS } & $I N V$ & INTR & $\begin{array}{l}1.155 \\
(0.158)^{* * * *}\end{array}$ & $\begin{array}{l}-0.846 \\
(0.445)^{*}\end{array}$ & \multirow[t]{2}{*}{2} & \multirow[t]{2}{*}{ yes } & \multirow[t]{2}{*}{$\begin{array}{l}1973- \\
2015\end{array}$} & \multirow[t]{2}{*}{4.43} \\
\hline & INTR & $I N V$ & $\begin{array}{l}0.797 \\
(0.149)^{* * *}\end{array}$ & $\begin{array}{l}0.113 \\
(0.053)^{* *}\end{array}$ & & & & \\
\hline \multirow[t]{2}{*}{ CAN } & $I N V$ & INTR & $\begin{array}{l}1.043 \\
(0.170)^{* * *}\end{array}$ & $\begin{array}{l}-0.478 \\
(0.431)\end{array}$ & \multirow[t]{2}{*}{2} & \multirow[t]{2}{*}{ yes } & \multirow[t]{2}{*}{$\begin{array}{l}1973- \\
2015\end{array}$} & \multirow[t]{2}{*}{4.16} \\
\hline & INTR & $I N V$ & $\begin{array}{l}0.730 \\
(0.155)^{* * *}\end{array}$ & $\begin{array}{l}0.138 \\
(0.061)^{* *}\end{array}$ & & & & \\
\hline \multirow[t]{2}{*}{ DEU } & $I N V$ & INTR & $\begin{array}{l}1.432 \\
(0.160)^{* * *}\end{array}$ & $\begin{array}{l}-1.136 \\
(0.405)^{* * *}\end{array}$ & \multirow[t]{2}{*}{2} & \multirow[t]{2}{*}{ yes } & \multirow[t]{2}{*}{$\begin{array}{l}1973- \\
2015\end{array}$} & \multirow[t]{2}{*}{7.07} \\
\hline & $I N T R$ & $I N V$ & $\begin{array}{l}0.511 \\
(0.163)^{* * * *}\end{array}$ & $\begin{array}{l}0.152 \\
(0.064) * *\end{array}$ & & & & \\
\hline \multirow[t]{2}{*}{ FIN } & $I N V$ & INTR & $\begin{array}{l}1.493 \\
(0.123) * * *\end{array}$ & $\begin{array}{l}-1.080 \\
(0.314)^{* * *}\end{array}$ & \multirow[t]{2}{*}{2} & \multirow[t]{2}{*}{ yes } & \multirow[t]{2}{*}{$\begin{array}{l}1972- \\
2015\end{array}$} & \multirow[t]{2}{*}{114.69} \\
\hline & INTR & $I N V$ & $\begin{array}{l}0.757 \\
(0.156)^{* * *}\end{array}$ & $\begin{array}{l}0.002 \\
(0.061)\end{array}$ & & & & \\
\hline \multirow[t]{2}{*}{ FRA } & $I N V$ & INTR & $\begin{array}{l}1.452 \\
(0.147)^{* * *}\end{array}$ & $\begin{array}{l}-0.548 \\
(0.335)\end{array}$ & \multirow[t]{2}{*}{2} & \multirow[t]{2}{*}{ yes } & \multirow[t]{2}{*}{$\begin{array}{l}1973- \\
2015\end{array}$} & \multirow[t]{2}{*}{$\begin{array}{c}\text { No complex } \\
\text { eigenvalue }\end{array}$} \\
\hline & INTR & $I N V$ & $\begin{array}{l}0.583 \\
(0.155)^{* * *}\end{array}$ & $\begin{array}{l}0.116 \\
(0.068)^{*}\end{array}$ & & & & \\
\hline \multirow[t]{2}{*}{ GBR } & $I N V$ & INTR & $\begin{array}{l}1.293 \\
(0.172)^{* * * *}\end{array}$ & $\begin{array}{l}-0.333 \\
(0.653)\end{array}$ & \multirow[t]{2}{*}{3} & \multirow[t]{2}{*}{ yes } & \multirow[t]{2}{*}{$\begin{array}{l}1981- \\
2015\end{array}$} & $\begin{array}{l}86.41 ; \\
5.41 ;\end{array}$ \\
\hline & INTR & $I N V$ & $\begin{array}{l}0.478 \\
(0.159)^{* * *}\end{array}$ & $\begin{array}{l}0.011 \\
(0.042)\end{array}$ & & & & 5.74 \\
\hline \multirow[t]{2}{*}{ USA } & $I N V$ & INTR & $\begin{array}{l}1.557 \\
(0.156)^{* * *}\end{array}$ & $\begin{array}{l}-1.574 \\
(0.635)^{* *}\end{array}$ & \multirow[t]{2}{*}{2} & \multirow[t]{2}{*}{ yes } & \multirow[t]{2}{*}{$\begin{array}{l}1973- \\
2015\end{array}$} & \multirow[t]{2}{*}{10.84} \\
\hline & INTR & $I N V$ & $\begin{array}{l}0.857 \\
(0.175)^{* * * *}\end{array}$ & $\begin{array}{l}0.052 \\
(0.043)\end{array}$ & & & & \\
\hline
\end{tabular}

Notes: AUS: Australia; CAN: Canada; DEU: Germany; FIN: Finland; FRA: France; GBR: Great Britain; USA: United States. DVL: Dependent variable. LDV: lagged dependent variable. EPV: first lag explanatory variable. Standard errors in parentheses. *,**,*** denote statistical significance at the 1,5 , and $10 \%$-level, respectively. Necessary condition: $\alpha_{2} \beta_{1}<0$. All specifications were estimated with a constant (not reported). 
Table A14: VAR models with INTR and CONS

\begin{tabular}{|c|c|c|c|c|c|c|c|c|}
\hline Country & DV & EPV & Coeff LDV & Coeff EPV & Lag order & $\begin{array}{l}\text { Necessary } \\
\text { condition } \\
\text { satisfied? }\end{array}$ & Period & $\begin{array}{l}\text { Cycle } \\
\text { length }\end{array}$ \\
\hline \multirow[t]{2}{*}{ AUS } & CONS & INTR & $\begin{array}{c}1.292 \\
(0.145)^{* * *}\end{array}$ & $\begin{array}{c}-0.219 \\
(0.081)^{* *}\end{array}$ & \multirow[t]{2}{*}{2} & \multirow[t]{2}{*}{ no } & \multirow[t]{2}{*}{$\begin{array}{l}1973- \\
2015\end{array}$} & \multirow{2}{*}{$\begin{array}{c}\text { No } \\
\text { complex } \\
\text { eigenvalue }\end{array}$} \\
\hline & INTR & CONS & $\begin{array}{c}0.793 \\
(0.158)^{* * *}\end{array}$ & $\begin{array}{l}-0.047 \\
(0.282)\end{array}$ & & & & \\
\hline \multirow[t]{2}{*}{$\overline{\text { CAN }}$} & CONS & INTR & $\begin{array}{c}1.354 \\
(0.179)^{* * *}\end{array}$ & $\begin{array}{c}-0.192 \\
(0.110)^{*}\end{array}$ & \multirow[t]{2}{*}{4} & \multirow[t]{2}{*}{ yes } & \multirow[t]{2}{*}{$\begin{array}{l}1975- \\
2015\end{array}$} & \multirow{2}{*}{$\begin{array}{c}36.52 \\
5.31 \\
2.86\end{array}$} \\
\hline & INTR & CONS & $\begin{array}{c}0.620 \\
(0177)^{* * *}\end{array}$ & $\begin{array}{c}0.551 \\
(0.287)^{*}\end{array}$ & & & & \\
\hline \multirow[t]{2}{*}{$\overline{\mathrm{DEU}}$} & CONS & INTR & $\begin{array}{c}1.429 \\
(0.144)^{* * *}\end{array}$ & $\begin{array}{c}-0.202 \\
(0.095)^{* *}\end{array}$ & \multirow[t]{2}{*}{2} & \multirow[t]{2}{*}{ yes } & \multirow[t]{2}{*}{$\begin{array}{l}1973- \\
2015\end{array}$} & \multirow[t]{2}{*}{141.58} \\
\hline & INTR & CONS & $\begin{array}{c}0.638 \\
(0.160)^{* * *}\end{array}$ & $\begin{array}{c}0.316 \\
(0.243)\end{array}$ & & & & \\
\hline \multirow[t]{2}{*}{ FIN } & CONS & INTR & $\begin{array}{c}1.526 \\
(0.126)^{* * *}\end{array}$ & $\begin{array}{c}-0.286 \\
(0.089)^{* * *}\end{array}$ & \multirow[t]{2}{*}{2} & \multirow[t]{2}{*}{ yes } & \multirow[t]{2}{*}{$\begin{array}{l}1972- \\
2015\end{array}$} & \multirow{2}{*}{$\begin{array}{c}\text { No } \\
\text { complex } \\
\text { eigenvalue }\end{array}$} \\
\hline & INTR & CONS & $\begin{array}{c}0.762 \\
(0.155)^{* * *}\end{array}$ & $\begin{array}{c}0.000 \\
(0.219)\end{array}$ & & & & \\
\hline \multirow[t]{2}{*}{ FRA } & CONS & INTR & $\begin{array}{c}1.176 \\
(0.157)^{* * *}\end{array}$ & $\begin{array}{l}-0.097 \\
(0.082)\end{array}$ & \multirow[t]{2}{*}{2} & \multirow[t]{2}{*}{ yes } & \multirow[t]{2}{*}{$\begin{array}{l}1973- \\
2015\end{array}$} & \multirow{2}{*}{$\begin{array}{c}\text { No } \\
\text { complex } \\
\text { eigenvalue }\end{array}$} \\
\hline & INTR & CONS & $\begin{array}{c}0.670 \\
(0.154)^{* * *}\end{array}$ & $\begin{array}{c}0.347 \\
(0.295)\end{array}$ & & & & \\
\hline \multirow[t]{2}{*}{ GBR } & CONS & INTR & $\begin{array}{c}1.658 \\
(0.183)^{* * *}\end{array}$ & $\begin{array}{l}-0.114 \\
(0.174)\end{array}$ & \multirow[t]{2}{*}{3} & \multirow[t]{2}{*}{ yes } & \multirow[t]{2}{*}{$\begin{array}{l}1981- \\
2015\end{array}$} & \multirow[t]{2}{*}{$\begin{array}{l}8.40 \\
3.62\end{array}$} \\
\hline & INTR & CONS & $\begin{array}{c}0.441 \\
(0.155)^{* * *}\end{array}$ & $\begin{array}{c}0.015 \\
(0.162)\end{array}$ & & & & \\
\hline \multirow[t]{2}{*}{ USA } & CONS & INTR & $\begin{array}{c}1.632 \\
(0.170)^{* * *}\end{array}$ & $\begin{array}{c}-0.274 \\
(0.149)^{*}\end{array}$ & \multirow[t]{2}{*}{3} & \multirow[t]{2}{*}{ yes } & \multirow[t]{2}{*}{$\begin{array}{l}1974- \\
2015\end{array}$} & \multirow[t]{2}{*}{$\begin{array}{c}24.58 \\
5.26\end{array}$} \\
\hline & INTR & CONS & $\begin{array}{l}0.914 \\
(0.160)^{* * *}\end{array}$ & $\begin{array}{l}0.482 \\
(0.183)^{* *}\end{array}$ & & & & \\
\hline
\end{tabular}

Notes: AUS: Australia; CAN: Canada; DEU: Germany; FIN: Finland; FRA: France; GBR: Great Britain; USA: United States. DVL: Dependent variable. LDV: lagged dependent variable. EPV: first lag explanatory variable. Standard errors in parentheses. *, **, *** denote statistical significance at the 1, 5, and 10\%-level, respectively. Necessary condition: $\alpha_{2} \beta_{1}<0$. All specifications were estimated with a constant (not reported). 
Table A15: VAR models with NFCD and INV

\begin{tabular}{|c|c|c|c|c|c|c|c|c|}
\hline Country & DV & EPV & $\begin{array}{l}\text { Coeff } \\
\text { LDV }\end{array}$ & $\begin{array}{l}\text { Coeff } \\
\text { EPV }\end{array}$ & $\begin{array}{l}\text { Lag } \\
\text { order }\end{array}$ & $\begin{array}{l}\text { Necessary } \\
\text { condition } \\
\text { satisfied? }\end{array}$ & Period & $\begin{array}{l}\text { Cycle } \\
\text { length }\end{array}$ \\
\hline \multirow[t]{2}{*}{ AUS } & $I N V$ & $N F C D$ & $\begin{array}{l}1.127 \\
(0.182)^{* * *}\end{array}$ & $\begin{array}{l}-0.132 \\
(0.304)\end{array}$ & \multirow[t]{2}{*}{2} & \multirow[t]{2}{*}{ no } & \multirow[t]{2}{*}{$\begin{array}{l}1979- \\
2015\end{array}$} & \multirow[t]{2}{*}{14.92} \\
\hline & $N F C D$ & $I N V$ & $\begin{array}{l}1.541 \\
(0.122)^{* * *}\end{array}$ & $\begin{array}{l}-0.009 \\
(0.073)\end{array}$ & & & & \\
\hline \multirow[t]{2}{*}{ CAN } & $I N V$ & NFCD & $\begin{array}{l}0.887 \\
(0.152)^{* * *}\end{array}$ & $\begin{array}{l}-0.381 \\
(0.274)\end{array}$ & \multirow[t]{2}{*}{3} & \multirow[t]{2}{*}{ yes } & \multirow[t]{2}{*}{$\begin{array}{l}1973- \\
2015\end{array}$} & \multirow[t]{2}{*}{$\begin{array}{l}15.25 ; \\
6.37\end{array}$} \\
\hline & NFCD & $I N V$ & $\begin{array}{l}1.435 \\
(0.178)^{* * *}\end{array}$ & $\begin{array}{l}0.204 \\
(0.098)^{* *}\end{array}$ & & & & \\
\hline \multirow[t]{2}{*}{ DEU } & $I N V$ & NFCD & $\begin{array}{l}1.333 \\
(0.179)^{* * *}\end{array}$ & $\begin{array}{l}0.012 \\
(0.568)\end{array}$ & \multirow[t]{2}{*}{3} & \multirow[t]{2}{*}{ yes } & \multirow[t]{2}{*}{$\begin{array}{l}1973- \\
2015\end{array}$} & \multirow[t]{2}{*}{$\begin{array}{l}7.10 \\
3.42\end{array}$} \\
\hline & NFCD & $I N V$ & $\begin{array}{l}1.060 \\
(0.164)^{* * *}\end{array}$ & $\begin{array}{l}-0.026 \\
(0.052)\end{array}$ & & & & \\
\hline \multirow[t]{2}{*}{ FIN } & $I N V$ & $N F C D$ & $\begin{array}{l}1.366 \\
(0.150)^{* * *}\end{array}$ & $\begin{array}{l}-0.358 \\
(0.215)\end{array}$ & \multirow[t]{2}{*}{2} & \multirow[t]{2}{*}{ no } & \multirow[t]{2}{*}{$\begin{array}{l}1972- \\
2015\end{array}$} & \multirow[t]{2}{*}{11.80} \\
\hline & NFCD & $I N V$ & $\begin{array}{l}0.876 \\
(0.168)^{* * *}\end{array}$ & $\begin{array}{l}0.167 \\
(0.117)\end{array}$ & & & & \\
\hline \multirow[t]{2}{*}{ FRA } & $I N V$ & $N F C D$ & $\begin{array}{l}1.442 \\
(0.162)^{* * *}\end{array}$ & $\begin{array}{l}-0.247 \\
(0.318)\end{array}$ & \multirow[t]{2}{*}{2} & \multirow[t]{2}{*}{ yes } & \multirow[t]{2}{*}{$\begin{array}{l}1979- \\
2015\end{array}$} & \multirow[t]{2}{*}{11.24} \\
\hline & NFCD & $I N V$ & $\begin{array}{l}1.269 \\
(0.153)^{* * *}\end{array}$ & $\begin{array}{l}0.300 \\
(0.078)^{* * *}\end{array}$ & & & & \\
\hline \multirow[t]{2}{*}{ GBR } & $I N V$ & NFCD & $\begin{array}{l}1.427 \\
(0.169)^{* * *}\end{array}$ & $\begin{array}{l}-0.038 \\
(0.106)\end{array}$ & \multirow[t]{2}{*}{2} & \multirow[t]{2}{*}{ yes } & \multirow[t]{2}{*}{$\begin{array}{l}1978- \\
2015\end{array}$} & \multirow[t]{2}{*}{8.77} \\
\hline & NFCD & $I N V$ & $\begin{array}{l}1.191 \\
(0.158)^{* * *}\end{array}$ & $\begin{array}{l}0.231 \\
(0.252)\end{array}$ & & & & \\
\hline \multirow[t]{2}{*}{ USA } & $I N V$ & NFCD & $\begin{array}{l}1.408 \\
(0.162)^{* * *}\end{array}$ & $\begin{array}{l}-0.838 \\
(0.794)\end{array}$ & \multirow[t]{2}{*}{3} & \multirow[t]{2}{*}{ yes } & \multirow[t]{2}{*}{$\begin{array}{l}1973- \\
2015\end{array}$} & \multirow[t]{2}{*}{$\begin{array}{l}9.67 ; \\
7.46\end{array}$} \\
\hline & NFCD & $I N V$ & $\begin{array}{l}1.922 \\
(0.150)^{* * *}\end{array}$ & $\begin{array}{l}0.131 \\
(0.031)^{* * *}\end{array}$ & & & & \\
\hline $\begin{array}{l}\text { Avr. cycle } \\
\text { length }\end{array}$ & & & & & & & & 11.25 \\
\hline
\end{tabular}

Notes: AUS: Australia; CAN: Canada; DEU: Germany; FIN: Finland; FRA: France; GBR: Great Britain; USA: United States. DVL: Dependent variable. LDV: lagged dependent variable. EPV: first lag explanatory variable. Standard errors in parentheses. *, **, *** denote statistical significance at the 1, 5, and 10\%-level, respectively. Necessary condition: $\alpha_{2} \beta_{1}<0$. All specifications were estimated with a constant (not reported). For the average cycle length, we use the longest implied cycle length of each country. 
Table A16: VAR models with CONS and $H H D$

\begin{tabular}{|c|c|c|c|c|c|c|c|c|}
\hline Country & DV & EPV & $\begin{array}{l}\text { Coeff } \\
\text { LDV }\end{array}$ & $\begin{array}{l}\text { Coeff } \\
\text { EPV }\end{array}$ & $\begin{array}{l}\text { Lag } \\
\text { order }\end{array}$ & $\begin{array}{l}\text { Necessary } \\
\text { condition } \\
\text { satisfied? }\end{array}$ & Period & $\begin{array}{l}\text { Cycle } \\
\text { length }\end{array}$ \\
\hline \multirow[t]{2}{*}{ AUS } & CONS & $H H D$ & $\begin{array}{l}1.175 \\
(0.178)^{* * *}\end{array}$ & $\begin{array}{l}0.015 \\
(0.120)\end{array}$ & \multirow[t]{2}{*}{3} & \multirow[t]{2}{*}{ yes } & \multirow[t]{2}{*}{$\begin{array}{l}1980- \\
2015\end{array}$} & \multirow[t]{2}{*}{4.33} \\
\hline & HHD & CONS & $\begin{array}{l}1.492 \\
(0.221)^{* * *}\end{array}$ & $\begin{array}{l}-0.087 \\
(0.328)\end{array}$ & & & & \\
\hline \multirow[t]{2}{*}{ CAN } & CONS & $H H D$ & $\begin{array}{l}1.595 \\
(0.150)^{* * *}\end{array}$ & $\begin{array}{l}0.239 \\
(0.109)^{* *}\end{array}$ & \multirow[t]{2}{*}{3} & \multirow[t]{2}{*}{ yes } & \multirow[t]{2}{*}{$\begin{array}{l}1973- \\
2015\end{array}$} & \multirow[t]{2}{*}{$\begin{array}{l}14.57 ; \\
3.37\end{array}$} \\
\hline & $H H D$ & CONS & $\begin{array}{l}1.454 \\
(0.151)^{* * *}\end{array}$ & $\begin{array}{l}-0.019 \\
(0.208)\end{array}$ & & & & \\
\hline \multirow[t]{2}{*}{ DEU } & CONS & $H H D$ & $\begin{array}{l}1.410 \\
(0.138)^{* * *}\end{array}$ & $\begin{array}{l}-0.146 \\
(0.095)\end{array}$ & \multirow[t]{2}{*}{3} & \multirow[t]{2}{*}{ yes } & \multirow[t]{2}{*}{$\begin{array}{l}1972- \\
2015\end{array}$} & \multirow[t]{2}{*}{37.94} \\
\hline & $H H D$ & CONS & $\begin{array}{l}1.598 \\
(0.122)^{* * *}\end{array}$ & $\begin{array}{l}0.048 \\
(0.177)\end{array}$ & & & & \\
\hline \multirow[t]{2}{*}{ FIN } & CONS & $H H D$ & $\begin{array}{l}1.698 \\
(0.170)^{* * *}\end{array}$ & $\begin{array}{l}0.218 \\
(0.161)\end{array}$ & \multirow[t]{2}{*}{5} & \multirow[t]{2}{*}{ no } & \multirow[t]{2}{*}{$\begin{array}{l}1972- \\
2015\end{array}$} & $\begin{array}{l}\text { 26.83; } \\
8.47 ;\end{array}$ \\
\hline & $H H D$ & CONS & $\begin{array}{l}1.297 \\
(0.137)^{* * *}\end{array}$ & $\begin{array}{l}0.218 \\
(0.145)\end{array}$ & & & & $\begin{array}{l}3.14 \\
3.89\end{array}$ \\
\hline \multirow[t]{2}{*}{ FRA } & CONS & $H H D$ & $\begin{array}{l}1.250 \\
(0.160)^{* * *}\end{array}$ & $\begin{array}{l}-0.030 \\
(0.128)\end{array}$ & \multirow[t]{2}{*}{5} & \multirow[t]{2}{*}{ yes } & \multirow[t]{2}{*}{$\begin{array}{l}1979- \\
2015\end{array}$} & \multirow[t]{2}{*}{46.90} \\
\hline & $H H D$ & CONS & $\begin{array}{l}1.623 \\
(0.125)^{* * *}\end{array}$ & $\begin{array}{l}0.311 \\
(0.157)^{*}\end{array}$ & & & & \\
\hline \multirow[t]{2}{*}{ GBR } & CONS & $H H D$ & $\begin{array}{l}1.445 \\
(0.155)^{* * *}\end{array}$ & $\begin{array}{l}-0.066 \\
(0.140)\end{array}$ & \multirow[t]{2}{*}{5} & \multirow[t]{2}{*}{ yes } & \multirow[t]{2}{*}{$\begin{array}{l}1972- \\
2015\end{array}$} & \multirow[t]{2}{*}{19.50} \\
\hline & $H H D$ & CONS & $\begin{array}{l}1.523 \\
(0.114)^{* * *}\end{array}$ & $\begin{array}{l}0.179 \\
(0.126)\end{array}$ & & & & \\
\hline \multirow[t]{2}{*}{ USA } & CONS & $H H D$ & $\begin{array}{l}1.371 \\
(0.156)^{* * *}\end{array}$ & $\begin{array}{l}-0.029 \\
(0.095)\end{array}$ & \multirow[t]{2}{*}{2} & \multirow[t]{2}{*}{ yes } & \multirow[t]{2}{*}{$\begin{array}{l}1972- \\
2015\end{array}$} & \multirow[t]{2}{*}{19.13} \\
\hline & $H H D$ & CONS & $\begin{array}{l}1.722 \\
(0.074)^{* * *}\end{array}$ & $\begin{array}{l}0.230 \\
(0.123)\end{array}$ & & & & \\
\hline $\begin{array}{l}\text { Avr. cycle } \\
\text { length }\end{array}$ & & & & & & & & 24.17 \\
\hline
\end{tabular}

Notes: AUS: Australia; CAN: Canada; DEU: Germany; FIN: Finland; FRA: France; GBR: Great Britain; USA: United States. DVL: Dependent variable. LDV: lagged dependent variable. EPV: first lag explanatory variable. Standard errors in parentheses. *, **, *** denote statistical significance at the 1, 5, and 10\%-level, respectively. Necessary condition: $\alpha_{2} \beta_{1}<0$. All specifications were estimated with a constant (not reported). For the average cycle length, we use the longest implied cycle length of each country. 
Table A17: VAR models with $I N V \_R E S$ and $H H D$

\begin{tabular}{|c|c|c|c|c|c|c|c|c|}
\hline Country & DV & EPV & $\begin{array}{l}\text { Coeff } \\
\text { LDV }\end{array}$ & $\begin{array}{l}\text { Coeff } \\
\text { EPV }\end{array}$ & $\begin{array}{l}\text { Lag } \\
\text { order }\end{array}$ & $\begin{array}{l}\text { Necessary } \\
\text { condition } \\
\text { satisfied? }\end{array}$ & Period & $\begin{array}{l}\text { Cycle } \\
\text { length }\end{array}$ \\
\hline \multirow[t]{2}{*}{ AUS } & $I N V \_R E S$ & $H H D$ & $\begin{array}{l}0.630 \\
(0.180)^{* * *}\end{array}$ & $\begin{array}{l}0.251 \\
(1.129)\end{array}$ & \multirow[t]{2}{*}{4} & \multirow[t]{2}{*}{ no } & \multirow[t]{2}{*}{$\begin{array}{l}1981- \\
2015\end{array}$} & \multirow{2}{*}{$\begin{array}{l}72.17 ; \\
4.44 ; \\
3.52\end{array}$} \\
\hline & $H H D$ & $I N V_{-} R E S$ & $\begin{array}{l}1.177 \\
(0.217)^{* * *}\end{array}$ & $\begin{array}{l}0.099 \\
(0.035)^{* * *}\end{array}$ & & & & \\
\hline \multirow[t]{2}{*}{ CAN } & $I N V_{-} R E S$ & HHD & $\begin{array}{l}0.908 \\
(0.165)^{* * *}\end{array}$ & $\begin{array}{l}-0.251 \\
(0.706)\end{array}$ & \multirow[t]{2}{*}{2} & \multirow[t]{2}{*}{ Yes } & \multirow[t]{2}{*}{$\begin{array}{l}1973- \\
2015\end{array}$} & \multirow[t]{2}{*}{26.23} \\
\hline & $H H D$ & $I N V_{-} R E S$ & $\begin{array}{l}1.413 \\
(0.134)^{* * *}\end{array}$ & $\begin{array}{l}0.030 \\
(0.031)\end{array}$ & & & & \\
\hline \multirow[t]{2}{*}{ DEU } & $I N V_{-} R E S$ & $H H D$ & $\begin{array}{l}1.302 \\
(0.168) * * *\end{array}$ & $\begin{array}{l}-0.444 \\
(0.524)\end{array}$ & \multirow[t]{2}{*}{2} & \multirow[t]{2}{*}{ no } & \multirow[t]{2}{*}{$\begin{array}{l}1982- \\
2015\end{array}$} & \multirow[t]{2}{*}{25.12} \\
\hline & $H H D$ & $I N V_{-} R E S$ & $\begin{array}{l}1.404 \\
(0.140)^{* * *}\end{array}$ & $\begin{array}{l}-0.033 \\
(0.045)\end{array}$ & & & & \\
\hline \multirow[t]{2}{*}{ FIN } & $I N V \_R E S$ & $H H D$ & $\begin{array}{l}0.875 \\
(0.193)^{* * *}\end{array}$ & $\begin{array}{l}4.078 \\
(1.140)^{* * *}\end{array}$ & \multirow[t]{2}{*}{5} & \multirow[t]{2}{*}{ yes } & \multirow[t]{2}{*}{$\begin{array}{l}1980- \\
2015\end{array}$} & $\begin{array}{l}20.40 \\
6.19\end{array}$ \\
\hline & $H H D$ & $I N V_{-} R E S$ & $\begin{array}{l}1.810 \\
(0.221)^{* * *}\end{array}$ & $\begin{array}{l}-0.033 \\
(0.037)\end{array}$ & & & & $\begin{array}{l}3.34 \\
2.66\end{array}$ \\
\hline \multirow[t]{2}{*}{ FRA } & $I N V \_R E S$ & $H H D$ & $\begin{array}{l}1.456 \\
(0.165)^{* * *}\end{array}$ & $\begin{array}{l}2.508 \\
(0.710)^{* * *}\end{array}$ & \multirow[t]{2}{*}{3} & \multirow[t]{2}{*}{ no } & \multirow[t]{2}{*}{$\begin{array}{l}1980- \\
2015\end{array}$} & \multirow[t]{2}{*}{$\begin{array}{l}17.55 ; \\
5.46\end{array}$} \\
\hline & $H H D$ & $I N V_{-} R E S$ & $\begin{array}{l}1.414 \\
(0.187)^{* * *}\end{array}$ & $\begin{array}{l}0.036 \\
(0.043)\end{array}$ & & & & \\
\hline \multirow[t]{2}{*}{ GBR } & $I N V_{-} R E S$ & $H H D$ & $\begin{array}{l}0.991 \\
(0.151)^{* * *}\end{array}$ & $\begin{array}{l}0.979 \\
(0.826)\end{array}$ & \multirow[t]{2}{*}{2} & \multirow[t]{2}{*}{ no } & \multirow[t]{2}{*}{$\begin{array}{l}1982- \\
2015\end{array}$} & \multirow[t]{2}{*}{$\begin{array}{l}76.47 ; \\
7.85\end{array}$} \\
\hline & $H H D$ & $I N V_{-} R E S$ & $\begin{array}{l}1.530 \\
(0.144)^{* * *}\end{array}$ & $\begin{array}{l}0.051 \\
(0.026)\end{array}$ & & & & \\
\hline \multirow[t]{2}{*}{ USA } & $I N V \_R E S$ & $H H D$ & $\begin{array}{l}0.965 \\
(0.189)^{* * *}\end{array}$ & $\begin{array}{l}4.730 \\
(2.089)^{* * *}\end{array}$ & \multirow[t]{2}{*}{6} & \multirow[t]{2}{*}{ no } & \multirow[t]{2}{*}{$\begin{array}{l}1976- \\
2015\end{array}$} & \multirow{2}{*}{$\begin{array}{l}19.96 ; \\
8.82 ; \\
5.30 ; \\
3.68 ; \\
2.49\end{array}$} \\
\hline & $H H D$ & $I N V \_R E S$ & $\begin{array}{l}1.879 \\
(0.183)^{* * *}\end{array}$ & $\begin{array}{l}0.035 \\
(0.017)^{* *}\end{array}$ & & & & \\
\hline $\begin{array}{l}\text { Avr. cycle } \\
\text { length }\end{array}$ & & & & & & & & 21.85 \\
\hline
\end{tabular}

Notes: AUS: Australia; CAN: Canada; DEU: Germany; FIN: Finland; FRA: France; GBR: Great Britain; USA:

United States. DVL: Dependent variable. LDV: lagged dependent variable. EPV: first lag explanatory variable.

Standard errors in parentheses. ${ }^{*}, * * * *$ denote statistical significance at the 1,5 , and $10 \%$-level, respectively. Necessary condition: $\alpha_{2} \beta_{1}<0$. All specifications were estimated with a constant (not reported). For the average cycle length, we use the longest implied cycle length of each country. 
Figure A1: Recursive estimates of $\alpha_{2}$ and $\beta_{1}$ for Canada, Germany, Finland, France and the USA, models with interest rate and investment

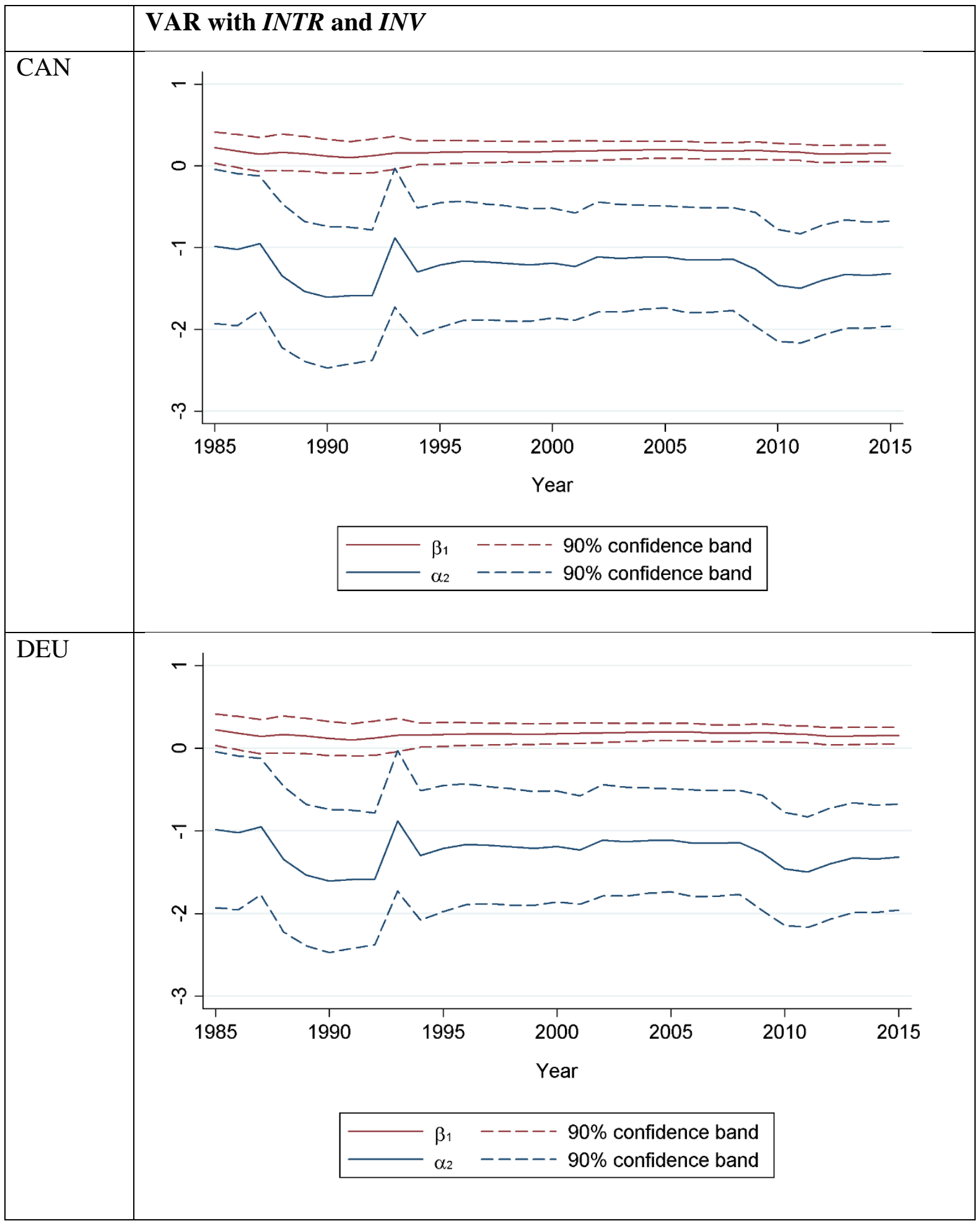




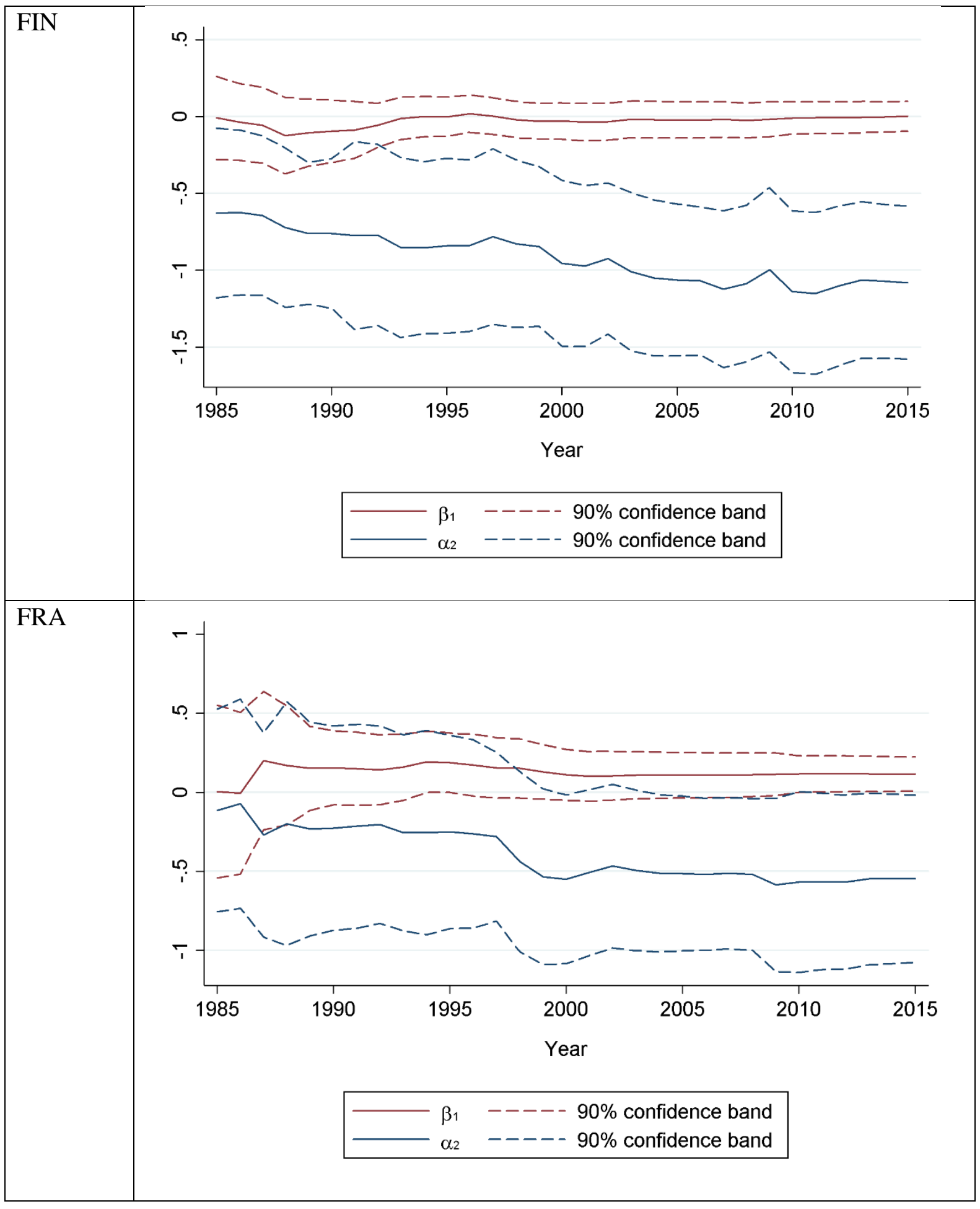




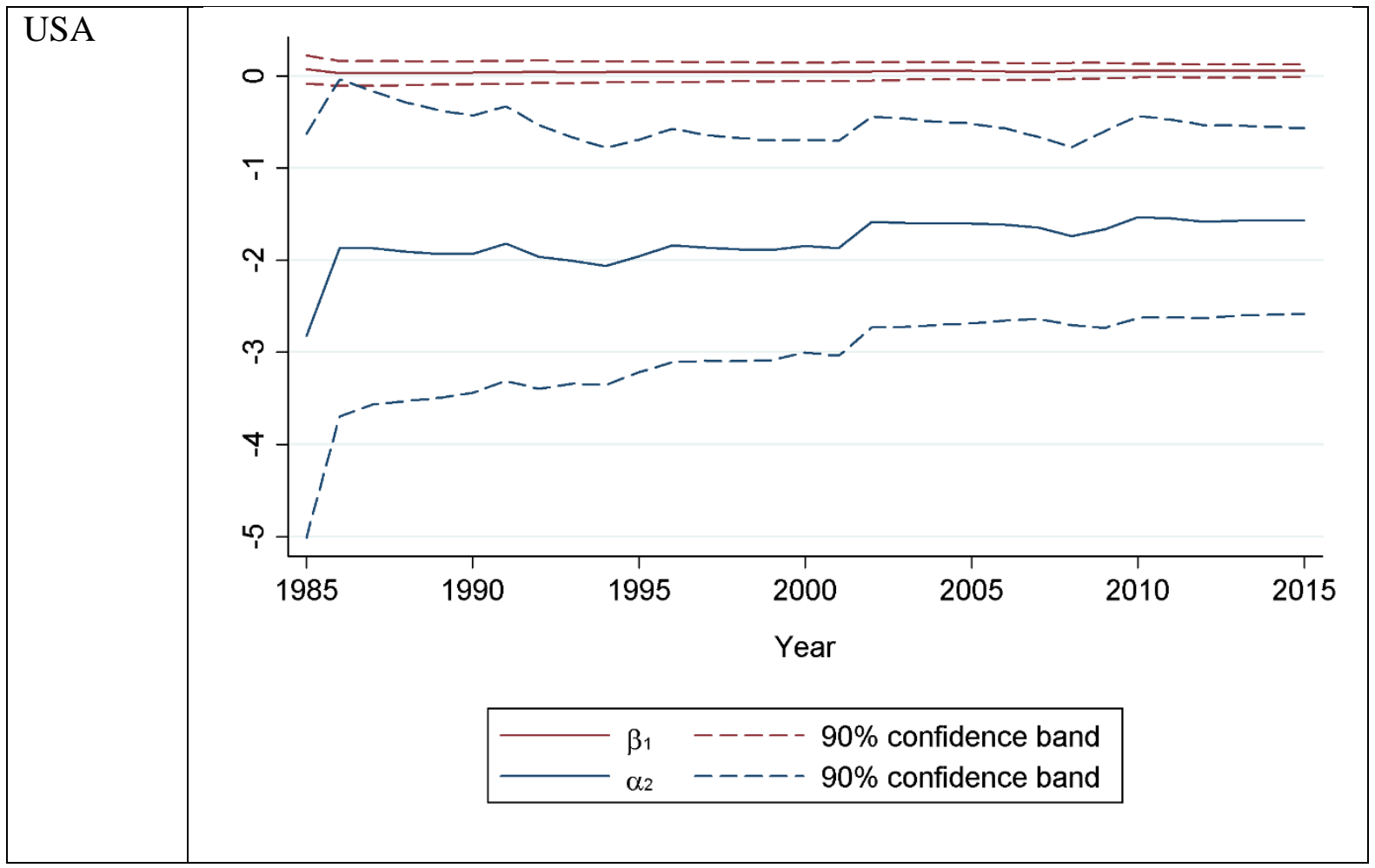

Figure A2: Recursive estimates of $\alpha_{2}$ and $\beta_{1}$ for Germany and the USA, models with interest rate and consumption

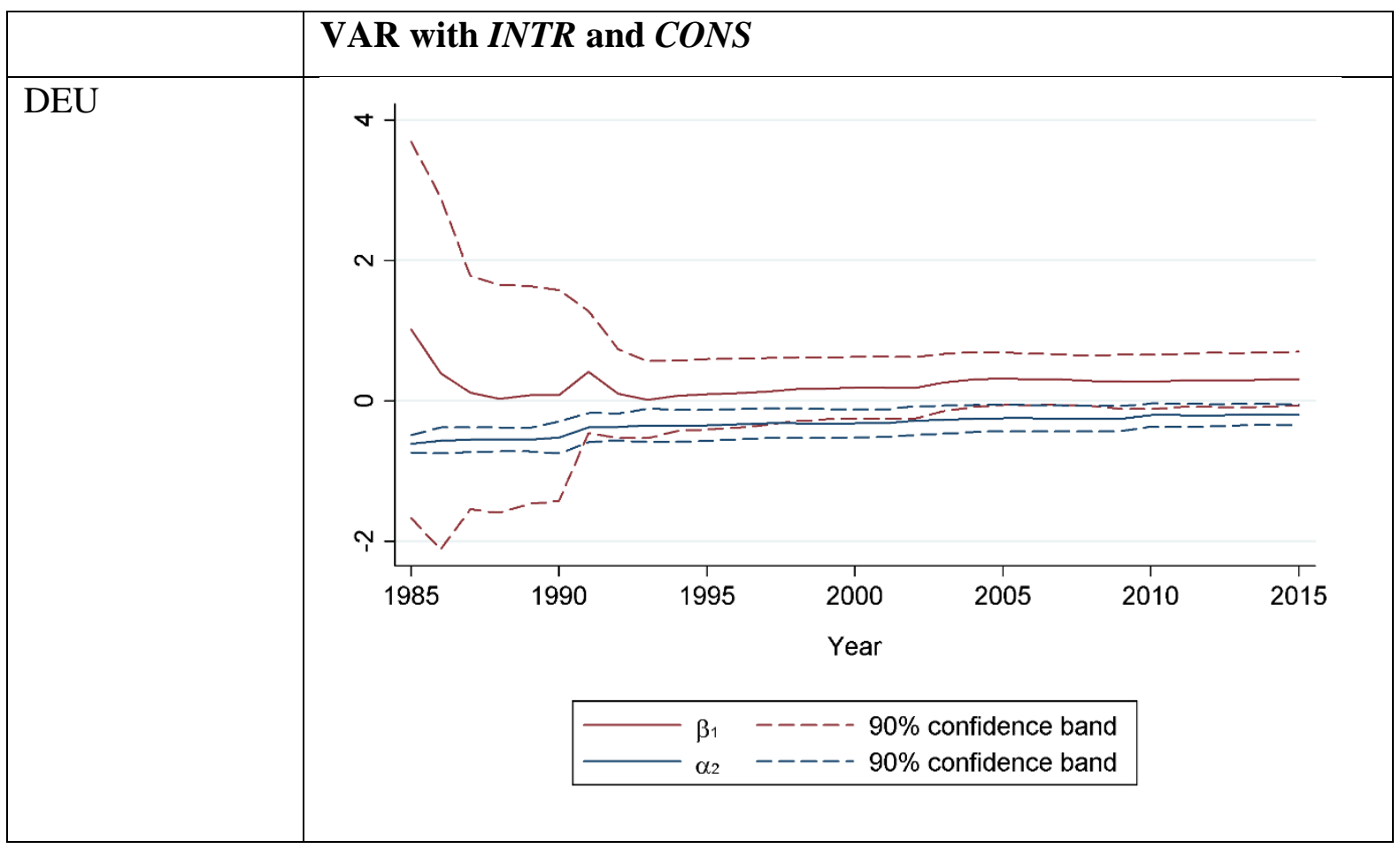




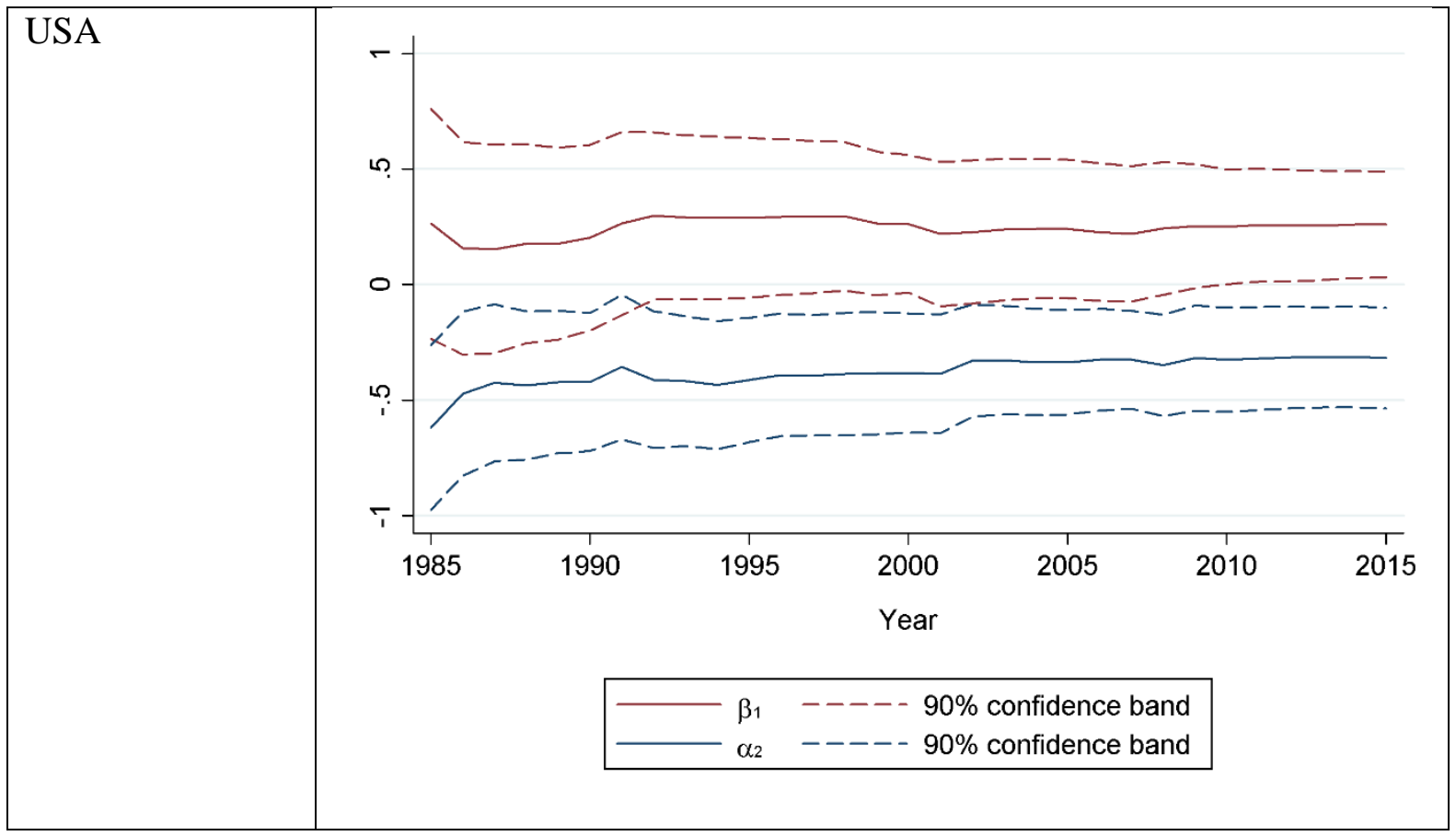

Figure A3: Recursive estimates of $\alpha_{2}$ and $\beta_{1}$ for Canada, Great Britain, and the USA, models with corporate debt and investment

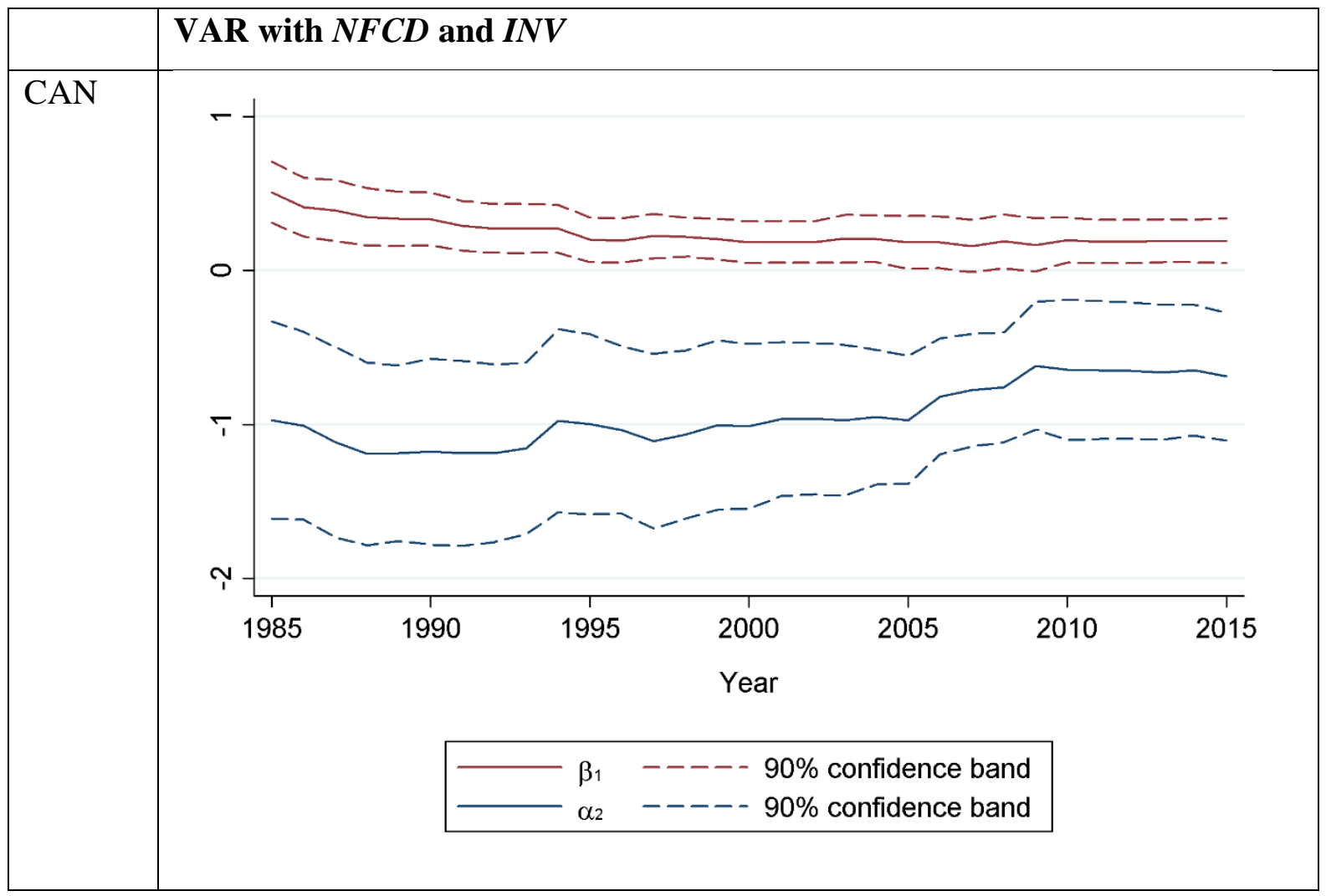




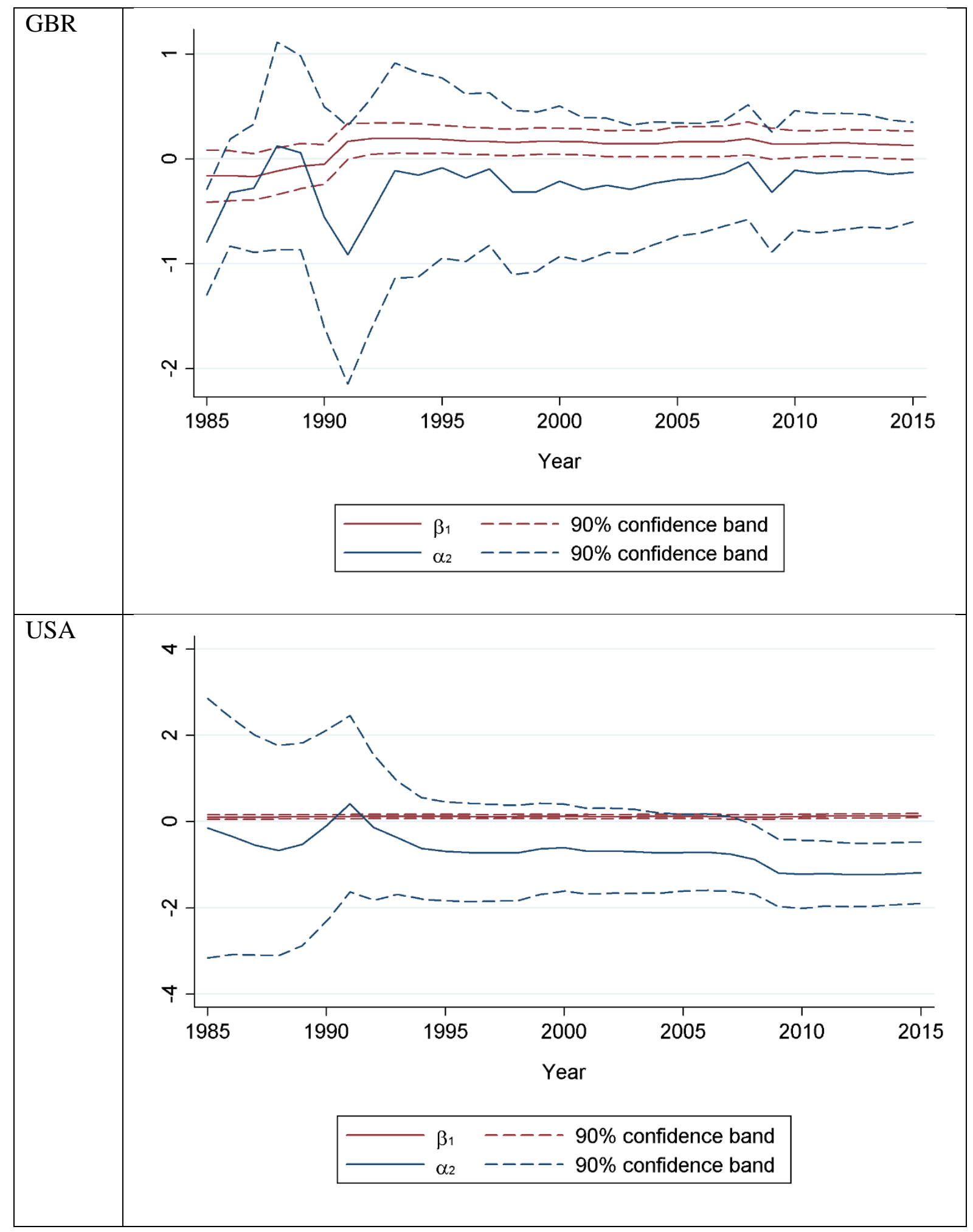


Figure A5: Recursive estimates of $\alpha_{2}$ and $\beta_{1}$ for the USA, models with household debt and consumption

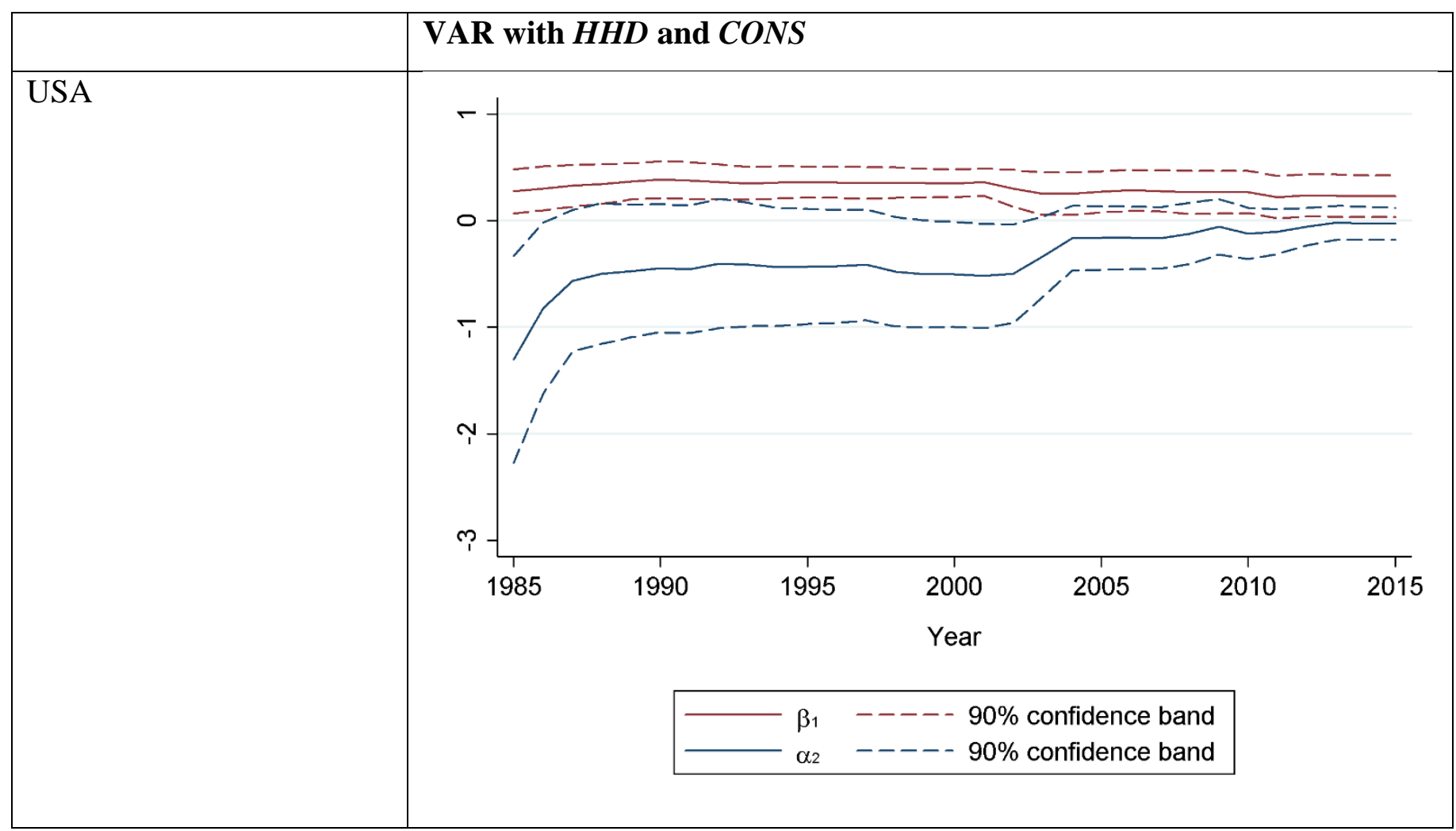

